\title{
Presynaptically Located CB1 Cannabinoid Receptors Regulate GABA Release from Axon Terminals of Specific Hippocampal Interneurons
}

\author{
István Katona, ${ }^{1}$ Beáta Sperlágh, ${ }^{1}$ Attila Sík, ${ }^{1}$ Attila Käfalvi, ${ }^{1}$ E. Sylvester Vizi, ${ }^{1}$ Ken Mackie, ${ }^{2}$ \\ and Tamás F. Freund ${ }^{1}$ \\ 1/nstitute of Experimental Medicine, Hungarian Academy of Sciences, Budapest, H-1450, Hungary, and 2Departments of \\ Anesthesiology, and Physiology and Biophysics, University of Washington, Seattle, Washington 98195
}

\begin{abstract}
To understand the functional significance and mechanisms of action in the CNS of endogenous and exogenous cannabinoids, it is crucial to identify the neural elements that serve as the structural substrate of these actions. We used a recently developed antibody against the CB1 cannabinoid receptor to study this question in hippocampal networks. Interneurons with features typical of basket cells showed a selective, intense staining for CB1 in all hippocampal subfields and layers. Most of them $(85.6 \%)$ contained cholecystokinin (CCK), which corresponded to $96.9 \%$ of all CCK-positive interneurons, whereas only $4.6 \%$ of the parvalbumin (PV)-containing basket cells expressed CB1. Accordingly, electron microscopy revealed that CB1-immunoreactive axon terminals of CCK-containing basket cells surrounded the somata and proximal dendrites of pyramidal neurons, whereas PV-positive basket cell terminals in similar locations were negative for CB1. The synthetic cannabinoid agonist WIN 55,212-2 (0.01-3 $\mu \mathrm{M})$ reduced dose-dependently
\end{abstract}

An increasing number of studies suggest that the well known behavioral effects of marijuana and hashish are generated by activation/modulation of an endogenous cannabinergic system in the brain. Identification and cloning of two types of cannabinoid receptors (CB1 and CB2) (Devane et al., 1988; Matsuda et al., 1990; Munro et al., 1993) initiated numerous studies investigating the molecular biology of CB1 receptors (Matsuda and Bonner, 1995), their pharmacological characteristics (Pertwee, 1997), and coupling with second messenger pathways (Childers and Deadwyler, 1996). Two potential endogenous substrates, anandamide (Devane et al., 1992) and sn-2 arachidonylglycerol (Stella et al., 1997), have also been characterized. However, to understand the role of these receptors and this novel chemical signaling system in the intact nervous system and the widespread behavioral effects of exogenous cannabinoids, a precise knowledge of their sites of action is required.

\footnotetext{
Received Dec. 23, 1998; revised March 5, 1999; accepted March 10, 1999.

This work was supported by the Howard Hughes Medical Institute, the McDonnell Foundation, and National Institutes of Health (NS30549) (T.F.F.); National Science Foundation of Hungary (T016756) (E.S.V., B.S.); National Institute on Drug Abuse Grants DA00286 and DA11322 (K.M.); and the Hungarian Soros Foundation (I.K.). We are grateful to Drs. T. J. Görcs and K. G. Baimbridge for antisera against cholecystokinin and parvalbumin, to E. Borók, E. Oszwald, and Gy Goda for excellent technical assistance, and to Dr. L. Acsády for the critical reading of this manuscript.

Correspondence should be addressed to Tamás F. Freund, Institute of Experimental Medicine, Hungarian Academy of Sciences, Budapest, P.O. Box 67, H-1450, Hungary.

Copyright (C) 1999 Society for Neuroscience 0270-6474/99/194544-15\$05.00/0
}

the electrical field stimulation-induced $\left[{ }^{3} \mathrm{H}\right] \mathrm{GABA}$ release from superfused hippocampal slices, with an $\mathrm{EC}_{50}$ value of 0.041 $\mu \mathrm{M}$. Inhibition of GABA release by WIN 55,212-2 was not mediated by inhibition of glutamatergic transmission because the WIN 55,212-2 effect was not reduced by the glutamate blockers AP5 and CNQX. In contrast, the CB1 cannabinoid receptor antagonist SR 141716A (1 $\mu \mathrm{M})$ prevented this effect, whereas by itself it did not change the outflow of $\left[{ }^{3} \mathrm{H}\right] \mathrm{GABA}$.

These results suggest that cannabinoid-mediated modulation of hippocampal interneuron networks operate largely via presynaptic receptors on CCK-immunoreactive basket cell terminals. Reduction of GABA release from these terminals is the likely mechanism by which both endogenous and exogenous CB1 ligands interfere with hippocampal network oscillations and associated cognitive functions.

Key words: interneurons; cannabinoids; GABA; inhibition; cholecystokinin; parvalbumin; hippocampus, anxiety

The major topographical distribution of CB1 in the brain has been examined first by autoradiography (Herkenham et al., 1990, 1991), then by in situ hybridization (Mailleux and Vanderhaeghen, 1992; Matsuda et al., 1993). The regional distribution of cannabinoid agonist-binding capacity and mRNA labeling correlates with the main behavioral effects of cannabinoids (Abood and Martin, 1992). Especially strong labeling for CB1 was found in the hippocampus of several species (Herkenham et al., 1990) in accordance with deficits in short-term (Heyser et al., 1993; Mallet and Beninger, 1998) and spatial memory tasks (Lichtman et al., 1995; Lichtman and Martin, 1996) after cannabinoid treatments. Although the precise mode of action of cannabimimetic agents on the hippocampal networks is still controversial, it has been suggested by several authors that modulation of GABAergic systems is an important component of their effects (Weisz et al., 1982; Kujtan et al., 1983; Collin et al., 1995; Coull et al., 1997; Paton et al., 1998).

By using a recently developed antibody against CB1, GABAergic interneurons of the hippocampus were shown to be strongly immunoreactive (Tsou et al., 1998, 1999). However, hippocampal interneurons possess a tremendous morphological, neurochemical, and electrophysiological diversity (for review, see Freund and Buzsáki, 1996; Vizi and Kiss, 1998). The different types of interneurons subserve different specific functions (Miles et al., 1996), e.g., they can control behavior-dependent electrical activity patterns (Ylinen et al., 1995), synaptic plasticity (Maccaferri and McBain, 1995), and synchronization of large populations of prin- 
cipal cells at slow and fast frequencies (Cobb et al., 1995; Whittington et al., 1995). Hence, to understand the role of cannabinoids and $\mathrm{CB} 1$ in the modulation of hippocampal GABAergic networks it is crucial to determine the precise cellular and subcellular distribution of the receptor along with its effect on GABA release.

Therefore, in the present study, first we aimed to identify the hippocampal interneuron types expressing the receptor. Subsequently, because the functional receptor can be present at several different domains of the cell, the precise subcellular localization of CB1 was also investigated. Moreover, we examined the effect of a $\mathrm{CB} 1$ agonist and antagonist on hippocampal GABA release to reveal the functional consequences of $\mathrm{CB} 1$-mediated presynaptic actions.

\section{MATERIALS AND METHODS}

Perfusion and preparation of tissue sections. The studies were conducted in accordance with the principles and procedures outlined in the NIH Guide for the Care and Use of Laboratory Animals. Eight male Wistar rats (300-350 gm, 2 months old; Charles River, Budapest, Hungary) were deeply anesthetized with Equithesin (chlornembutal, $0.3 \mathrm{ml} / 100 \mathrm{gm}$ ) and perfused through the heart first with saline, followed by a phosphatebuffered $(\mathrm{PB}, 0.1 \mathrm{M})$ fixative containing $4 \%$ paraformaldehyde, $0.2 \%$ picric acid, and $0.05 \%$ glutaraldehyde in series $\mathrm{A}(n=4)$ for single CB1-immunostaining and the mirror experiments. In series $\mathrm{B}(n=4$ animals) the fixative also contained $4 \%$ paraformaldehyde and $0.2 \%$ picric acid, but glutaraldehyde was not added. This fixative was used for pre-embedding immunogold staining for CB1 combined with a second immunostaining for parvalbumin (PV) or cholecystokinin (CCK). Brains were removed from the skull, blocks of the hippocampus and overlying neocortex were dissected, and coronal sections of $60 \mu \mathrm{m}$ thickness were cut on a vibratome. After extensive washes the sections were cryoprotected in $25 \%$ sucrose and $10 \%$ glycerol in $0.1 \mathrm{M} \mathrm{PB}$ overnight, and freeze-thawed in an aluminum-foil boat over liquid nitrogen to enhance the penetration of antisera without destroying the ultrastructure. The sections prepared for light microscopic examination of CB1immunoreactive neurons were treated with $0.5 \%$ Triton $\mathrm{X}-100$ diluted in 0.05 M Tris-buffered saline (TBS) also containing 5\% bovine serum albumin (BSA).

Pre-embedding immunocytochemistry. After extensive washes with buffer, the sections were incubated first in 5\% BSA (45 min) and then in solutions of one of the following antisera: rabbit anti-CB1 diluted 1:1000 (Tsou et al., 1998) or rabbit anti-PV 1:1500 (Baimbridge and Miller, 1982) or rabbit anti-CCK 1:10,000 (Gulyás et al., 1990). After $48 \mathrm{hr}$ and subsequent extensive washing, the sections were incubated with biotinylated anti-rabbit $\operatorname{IgG}$ (Vector Laboratories, Burlingame, CA; $2 \mathrm{hr}$, 1:400) followed by avidin-biotinylated horseradish peroxidase complex (Elite ABC, Vector; $1.5 \mathrm{hr}, 1: 400$ ). The immunoperoxidase reaction was developed using 3,3' diaminobenzidine (DAB; Sigma, St. Louis, MO) intensified with ammonium nickel sulfate (DAB-Ni) as a chromogen (black reaction product). The sections were treated with $1 \%$ osmium tetroxide in $0.1 \mathrm{M}$ PB for $10 \mathrm{~min}$, dehydrated in ascending alcohol series and propylene oxide, and embedded in Durcupan (ACM, Fluka, Buchs, Switzerland).

Pre-embedding immunogold staining combined with second immunoperoxidase staining. After incubation with the primary antibody (CB1 $1: 1000)$ and several washes, sections were blocked in $0.8 \%$ BSA, $0.1 \%$ IGGS (ImmunoGold Silver Staining) quality gelatin (Amersham Life Science, Little Chalfont, England) and 5\% normal goat serum in TBS for $30 \mathrm{~min}$. This was followed by incubation with $1 \mathrm{~nm}$ gold-labeled goat anti-rabbit IgG (Amersham Life Science) diluted 1:50 in $0.8 \%$ BSA, $0.1 \%$ IGGS gelatin, and $1 \%$ normal goat serum in TBS for $6 \mathrm{hr}$. After the incubation, the sections were washed and post-fixed with $1 \%$ glutaraldehyde in TBS for $10 \mathrm{~min}$. The $1 \mathrm{~nm}$ gold particles were silver-enhanced by IntenSE M (Amersham Life Science) for 5-10 min. In doubleimmunostaining experiments, silver enhancement was followed by several washes and by incubation in the primary antibody of the second round, then the same steps were used as in single staining except that simple (not nickel-intensified) DAB was used as chromogen. The sections were treated with $1 \%$ osmium tetroxide in $0.1 \mathrm{M} \mathrm{PB}$ for $1 \mathrm{hr}$, dehydrated in ethanol and propylene oxide, and embedded in Durcupan
(ACM, Fluka). During dehydration, the sections were treated with $1 \%$ uranyl acetate in $70 \%$ ethanol for $45 \mathrm{~min}$.

For electron microscopic investigations, selected immunoreactive profiles and regions (somata and the principal cell layers in CA 3 and CA1 subfields) were photographed, drawn, and re-embedded for further ultrathin sectioning. At the electron microscopic level, the same profiles were identified, and the localization of the gold particles was examined. The electron micrographs were taken on a Hitachi 7100 electron microscope.

Controls. The specificity of the primary antisera has been tested in the laboratories of origin (see references above). Moreover, when we preabsorbed the CB1 antisera with the immunizing protein $(1 \mu \mathrm{g} / \mathrm{ml})$, specific immunostaining was not visible. In double-stained sections each antisera gave the same staining pattern as if applied in single staining. Although the primary antisera in both cycles were raised in rabbit, the end product of the silver enhancement reaction masked the immune complex so that the antisera of the second cycle could not bind to the first. Replacing the primary antisera with normal rabbit serum resulted in the lack of specific immunostaining; only a faint nuclear background staining was present on the surface of the sections.

Evaluation of colocalization at the light microscopic level. To study the coexistence of CB1 cannabinoid receptors with PV or CCK at the light microscopic level, the mirror technique of Kosaka et al. (1985) was used. The analysis was carried out in both the dorsal and ventral hippocampus (5-10 section pairs from three animals). Adjacent sections were reacted for CB1 and for one of the other antigens, and bisected cell bodies were identified on the common surfaces of both sections using capillaries as landmarks. First, bisected immunopositive cell bodies were identified on the surface of the sections using a $100 \times$ oil immersion objective. Then, the corresponding halves of the somata were found on the matching surface of the adjacent section. Cells were only included in the analysis if the matching other half could be identified unequivocally (whether negative or positive).

Evaluation of colocalization at the electron microscopic level. CCK- or $\mathrm{PV}$-immunoreactive boutons were searched for randomly in serial sections, and when they formed a synapse, the silver-gold particles labeling $\mathrm{CB} 1$ on the presynaptic element were examined. Each bouton was followed through at least 10 serial sections, and the number of gold particles located along the outside of the presynaptic plasma membrane was counted. Because the antibody recognizes the N-terminal domain of $\mathrm{CB} 1$, which is located extracellularly as in other G-protein-coupled receptors, the occasional gold particles inside the terminals were not included in the counts. Boutons were regarded as positive for CB1 if at least four gold particles were found in 10 sections around the level where they formed a synapse. Boutons were regarded as negative for CB1 if no gold particles were located around their membrane through 10 sections. Boutons with one to three gold particles were considered as unidentified. Boutons were considered positive for PV or CCK if strong DAB precipitate was found inside the terminal. In the case of CB1/PV doubleimmunostaining, the two markers were not colocalized. Therefore only PV-immunopositive boutons, which were located close to CB1-positive boutons, were examined to avoid false-negative results attributable to occasional penetration problems of pre-embedding immunogold staining.

$\left[{ }^{3} H\right] G A B A$ release experiments. The experiments were performed on male Wistar rats (160-180 gm, Richter Gedeon, Budapest, Hungary). The animals were decapitated, and the brain was quickly removed to ice-cold Krebs' solution of the following composition (in $\mathrm{mM}$ ): $\mathrm{NaCl} 115$, $\mathrm{KCl} 3, \mathrm{KH}_{2} \mathrm{PO}_{4} 1.2, \mathrm{MgSO}_{4} 1.2, \mathrm{CaCl}_{2} 2.5, \mathrm{NaHCO}_{3} 25$, glucose 10, pH 7.4 , oxygenated with $95 \% \quad \mathrm{O}_{2}$ and $5 \% \quad \mathrm{CO}_{2}$. The hippocampus was dissected and $400-\mu \mathrm{m}$-thick slices were cut with a McIlwain tissue chopper and loaded with 4-amino- $n-\left[2,3-{ }^{3} \mathrm{H}\right]$ butyric acid $\left(\left[{ }^{3} \mathrm{H}\right]\right.$ GABA, Amersham; specific activity $86 \mathrm{Ci} / \mathrm{mmol}, 4 \mu \mathrm{Ci} / \mathrm{ml}$ ) in $1 \mathrm{ml} \mathrm{Krebs's} \mathrm{solution}$ for $60 \mathrm{~min}$ at $37^{\circ} \mathrm{C}$. The incubating solution was supplemented with $\beta$-alanine (1 mm, Tocris Cookson) to prevent tritium uptake into glial cells (Iversen and Kelly, 1975; Kelly and Dick, 1976). The slices were then rinsed three times with $6 \mathrm{ml}$ Krebs' solution, transferred to a polypropylene perfusion chamber of $100 \mu \mathrm{l}$, and perfused with oxygenated Krebs' solution for $60 \mathrm{~min}$ with a flow rate of $0.7 \mathrm{ml} / \mathrm{min}$. To minimize the formation of GABA metabolites, the perfusion solution contained aminooxyacetic acid (100 $\mu \mathrm{M}$, Sigma) (Bernáth and Zigmond, 1988; Vizi, 1998). After the preperfusion period, 3-min samples of the effluent were collected and assayed for radioactivity by liquid scintillation spectroscopy. Electrical field stimulation was applied through platinum ring electrodes twice, 6 and 36 min after the beginning of the collection period $\left(\mathrm{S}_{1}, \mathrm{~S}_{2}\right)$. Bipolar square-wave pulses were delivered by a Grass 
S88 Stimulator (Grass Medical Instruments, Quincy, MA) at $35 \mathrm{~V}, 3$ msec, at a frequency of $2 \mathrm{~Hz}$ for $3 \mathrm{~min}$ (360 pulses). Previous studies showed that the majority of tritium release under comparable conditions represents $\left[{ }^{3} \mathrm{H}\right] \mathrm{GABA}$ (Okada and Hassler, 1973; Limberger et al., 1986; Hársing and Zigmond, 1998), and the stimulation-evoked release is tetrodotoxin-sensitive, i.e., it is of neuronal origin (Bernáth and Zigmond, 1988; Vizi, 1998). The CB1 cannabinoid receptor agonist WIN 55,212-2 (RBI, Natick, MA) was applied in different concentrations ranging from 0.01 to $3 \mu \mathrm{M}$, in the Krebs' solution $18 \mathrm{~min}$ before the second stimulation period $\left(\mathrm{S}_{2}\right)$ and perfused until the end of the experiment. The NMDA receptor antagonist 2-amino-5-phosphonopentanoic acid (AP-5, $10 \mu \mathrm{M}$; RBI), the non-NMDA receptor antagonist 6-cyano7-nitroquinoxaline-2,3-dione sodium (CNQX, $10 \mu \mathrm{M}$; RBI), and the CB1-receptor antagonist SR141716A (1 $\mu \mathrm{M}$, NIDA) were applied $15 \mathrm{~min}$ before the first stimulation $\left(\mathrm{S}_{1}\right)$ and perfused thereafter, or in some experiments $18 \mathrm{~min}$ before the second stimulation period $\left(\mathrm{S}_{2}\right)$. WIN $55,212-2$ was dissolved in 2-hydroxypropyl- $\beta$-cyclodextrin (RBI), and SR141716A was dissolved in 100\% dimethylsulfoxide (DMSO, Sigma); the final concentration of DMSO was $0.001 \%$. Control solutions always contained the appropriate concentration of 2-hydroxypropyl- $\beta$ cyclodextrin or DMSO. DMSO alone at this concentration did not significantly affect the resting and the stimulation-evoked efflux of $\left[{ }^{3} \mathrm{H}\right] \mathrm{GABA}$ : the $\mathrm{R}_{2} / \mathrm{R}_{1}$ and $\mathrm{S}_{2} / \mathrm{S}_{1}$ ratios were $0.90 \pm 0.05$ and $0.96 \pm 0.13$ in the presence of DMSO, respectively ( $n=6, p>0.05$ vs control). At the end of the experiments, tissues were homogenized by sonication in $0.5 \mathrm{ml} 10 \%$ trichloroacetic acid, and a $100 \mu \mathrm{l}$ aliquot was used to determine the amount of radioactivity that remained in the preparations. The tritium content of the samples was assayed by adding a $0.5 \mathrm{ml}$ aliquot of the perfusate samples to $2.5 \mathrm{ml}$ liquid scintillation fluid (Packard Ultima Gold) and counted in a Packard Tricarb 1500 Scintillation spectrometer for $2 \mathrm{~min}$. Radioactivity was expressed as disintegrations per minute per gram of tissue $(\mathrm{Bq} / \mathrm{gm})$ or as fractional release, i.e., as a percentage of the total radioactivity in the tissue at the time of sample collection. The uptake of $\left[{ }^{3} \mathrm{H}\right]$ was determined as the sum release + tissue content of radioactivity after the experiment. The release of tritium evoked by field stimulation (stimulation evoked release $S_{1}, S_{2}$ ) was calculated by the area-under-the-curve method, i.e., subtracting the resting release, measured during the prestimulation period, from the release during the stimulation and after the stimulation period. The effect of the drugs on the field stimulation-evoked $\left[{ }^{3} \mathrm{H}\right] \mathrm{GABA}$ release was evaluated as the $S_{2} / S_{1}$ ratio compared with the $S_{2} / S_{1}$ ratio obtained in the absence of the drug. The effects of the drugs on the basal outflow of tritium was determined by comparing the release in the corresponding prestimulation samples $\left(\mathrm{R}_{1}, \mathrm{R}_{2}\right)$ in the absence and presence of drugs, respectively. All data represent the mean \pm SEM of $n$ observations. Statistical significance was calculated by the two-tailed Student's $t$ test or one-way ANOVA followed by Dunnett test, and $p<0.05$ was accepted as significant change.

In some experiments the effect of WIN 55,212-2 was evaluated on [ $\left.{ }^{3} \mathrm{H}\right]$ GABA uptake: hippocampal slices were incubated in $1 \mathrm{ml} \mathrm{Krebs}$ ' solution containing $\left[{ }^{3} \mathrm{H}\right] \mathrm{GABA}(4 \mu \mathrm{Ci} / \mathrm{ml})$ and WIN 55,212-2 $(1 \mu \mathrm{M})$ and $1 \mathrm{~mm} \beta$-alanine for $60 \mathrm{~min}$ at $37^{\circ} \mathrm{C}$, whereas control slices were incubated under identical conditions in the absence of the cannabinoid agonist. At the end of this period tissue slices were rinsed, and radioactivity was extracted and measured as described above.

\section{RESULTS}

\section{General pattern of CB1 cannabinoid receptor-immunostaining in the hippocampus}

The general light microscopic pattern of CB1 cannabinoid receptor (CB1)-immunostaining was similar to that described earlier (Tsou et al., 1998). Only neuronal profiles, namely somata, proximal but not distal dendrites, and axons were immunoreactive. In the hippocampus, the most characteristic feature was the selective staining of numerous cell bodies resembling interneurons in all subfields (Fig. 1). In the dorsal hippocampus, on average $173.2 \pm$ 13.8 cell bodies were labeled in a $60-\mu \mathrm{m}$-thick section $(167.3 \pm$ 11.6 in animal $1 ; 170.0 \pm 17.6$ in animal $2 ; 182.3 \pm 4.7$ in animal 3 ; averaged from nine sections). Cell bodies were found predominantly at the border of stratum granulosum and the hilus in the dentate gyrus (Fig. $1 D)(62.0 \%$ of all CB1-immunoreactive cell bodies in the dentate gyrus), in stratum radiatum of the CA3 subfield (Fig. 1C) (64.1\% of all CB1-positive cell bodies in CA3), and at the border of strata lacunosum-moleculare and radiatum of the CA1 subfield (Fig. $1 B)(47.4 \%$ of all CB1-immunoreactive cell bodies in CA1). However, CB1-immunoreactive interneurons were also found in all other layers in smaller numbers. In animals with poor perfusion, and without glutaraldehyde, principal cells of the CA3 and CA1 subfields were also labeled, although much weaker than in Pettit et al. (1998), who used a different antibody for CB1. However, the parameters of perfusion or developing, which gave rise to this staining pattern, were variable and irreproducible. Moreover, the labeling of principal cells was always extremely weak compared with interneurons. Thus, at this point we consider this occasional pyramidal cell staining in poorly fixed tissue as technical background and limit our attention to the distribution of CB1 in hippocampal interneurons. On the other hand, the possibility that principal cells express the receptor in very small amounts cannot be ruled out, especially in the light of in situ hybridization studies (Mailleux and Vanderhaeghen, 1992; Matsuda et al., 1993).

\section{Morphological classification of CB1-immunoreactive neurons}

Generally, only the proximal dendritic tree of interneurons was labeled, which limited their identification on morphological grounds. Nevertheless, some characteristic types of CB1immunoreactive neurons could be defined. In the dentate gyrus, cells of the most common type were located at the border of stratum granulosum and the hilus, and an apical main dendrite could be followed up to the stratum moleculare (Fig. $1 D$, see Fig. $3 A, B)$. Beside this cell type, large $\mathrm{CB} 1$-immunoreactive neurons with multipolar dendritic trees were observed both in the hilus and stratum moleculare. The axonal staining in the dentate gyrus showed a characteristic pattern. The innermost part of the stratum moleculare showed a dense band of immunostained axons (Fig. 1A,D), whereas in the hilus, large basket-like arrays of CB1-positive boutons were found around many but not all CB1negative cell bodies.

In the CA3 subfield, most of the CB1-positive cells with multipolar dendritic tree were located in stratum radiatum (Fig. 1C). In stratum pyramidale, all immunonegative cell bodies were surrounded by numerous CB1-immunoreactive boutons (Fig. $1 C$ ). In the CA1 subfield, the most typical interneurons with multipolar dendritic trees were located at the border of strata lacunosummoleculare and radiatum (Fig. $1 B$; see Fig. $3 E, F$ ). Large neurons with bitufted dendritic arbors were also common in strata radiatum and pyramidale (Fig. $1 B$; see Fig. $3 G, H$ ). The basket terminals in the pyramidal cell layer were present in this subfield as well, but in addition, a narrow band of immunoreactive boutons was observed at the border of strata pyramidale and radiatum (Fig. 1B).

\section{CB1 cannabinoid receptors are expressed in cholecystokinin- but not in parvalbumin- immunoreactive basket cells in the hippocampus}

The characteristic pattern of CB1-immunostaining, namely the strong immunoreactivity of axon terminals in the principal cell layers, suggested that one or both basket cell populations express the receptor. To test this hypothesis we examined whether CB1 colocalizes with the calcium-binding protein $\mathrm{PV}$, a neurochemical marker of one of the two basket cell populations (Katsumaru et al., 1988; for review, see Freund and Buzsáki, 1996), or with the neuropeptide CCK, the marker for the other subtype (Nunzi et al., 1985; Acsády et al., 1996a,b) (Table 1). By using the mirror 

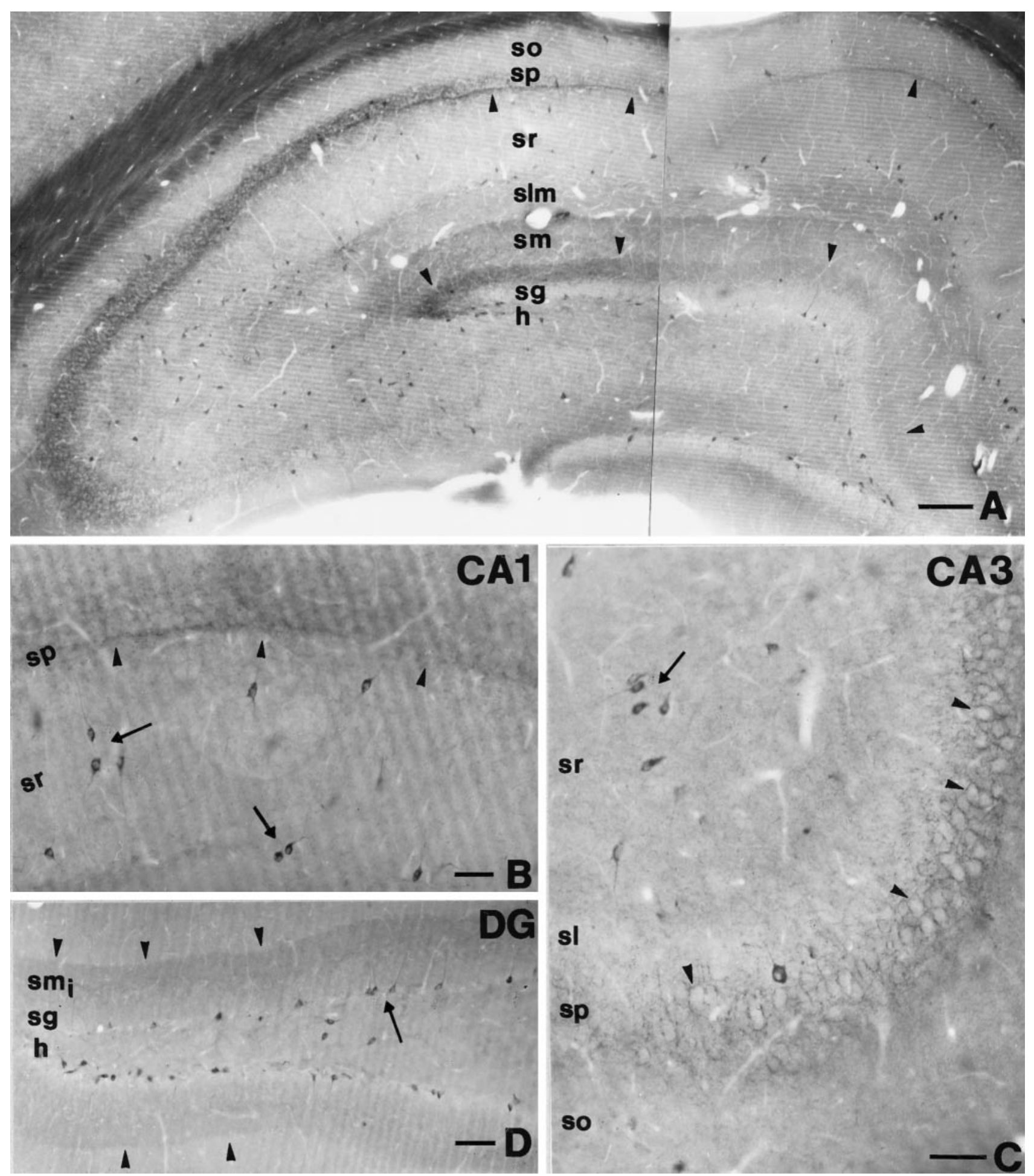

Figure 1. A, Low-power light micrograph showing CB1-immunostaining in the dorsal hippocampus. Arrowheads indicate characteristic CB1immunopositive bands in the inner third of stratum moleculare and at the border of strata pyramidale and radiatum in the CA1 subfield. Note that most CB1-immunoreactive cell bodies resembling interneurons are distributed in all subfields and layers of the hippocampus. $B$, In the CA1 subfield, arrows depict typical CB1-positive interneurons with multipolar, thin proximal dendrites located at the border of strata radiatum and lacunosum-moleculare, and interneurons with a bitufted dendritic tree in the middle part of stratum radiatum. Although immunostained axon terminals covered the entire stratum pyramidale, an even denser band of axonal staining was observed at the border of strata pyramidale and radiatum (arrowheads). $C$, In the CA3 subfield, this band was absent in stratum lucidum, whereas a dense meshwork of CB1-immunostained basket-like axons surrounded the immunonegative somata of pyramidal cells (arrowheads) as in CA1. Most of the CB1-positive cell bodies were found in stratum radiatum (arrow). D, In the dentate gyrus, most of the CB1-immunoreactive cell bodies were located at the border of the hilus and stratum granulosum (arrow). The apical dendrites of these cells crossed stratum granulosum without branching. Arrowheads indicate dense punctate immunostaining in the inner third of stratum moleculare. $D G$, Dentate gyrus; $h$, hilus; $s g$, stratum granulosum; $s m i$, inner third of stratum moleculare; sm, stratum moleculare; $s l m$, stratum lacunosum-moleculare; $s r$, stratum radiatum; $s p$, stratum pyramidale; so, stratum oriens; sl, stratum lucidum. Scale bars: $A, 200 \mu \mathrm{m} ; B, C, 60 \mu \mathrm{m} ; D, 100 \mu \mathrm{m}$. 
Table 1. Occurrence of CB1 in CCK- or PV-immunoreactive cell bodies

\begin{tabular}{|c|c|c|c|c|c|}
\hline & \multicolumn{2}{|l|}{$\mathrm{CCK}$} & & \multicolumn{2}{|l|}{ PV } \\
\hline & $\mathrm{CB} 1+(\%)$ & $\mathrm{CB} 1-(\%)$ & & $\mathrm{CB} 1+(\%)$ & $\mathrm{CB} 1-(\%)$ \\
\hline CA1 $(n=30)$ & $30(100.0)$ & $0(0.0)$ & $\mathrm{CA} 1(n=70)$ & $3(4.3)$ & 67 (95.7) \\
\hline $\mathrm{CA} 3(n=30)$ & $29(96.6)$ & $1(3.3)$ & $\mathrm{CA} 3(n=31)$ & $3(9.7)$ & $28(90.3)$ \\
\hline $\mathrm{DG}(n=37)$ & $35(94.6)$ & $2(5.4)$ & $\mathrm{DG}(n=29)$ & $0(0.0)$ & $29(100.0)$ \\
\hline Total $(n=97)$ & $94(96.9)$ & $3(3.1)$ & Total $(n=130)$ & $6(4.6)$ & $124(95.4)$ \\
\hline
\end{tabular}

The mirror technique was used to establish the proportion of CCK- or PV-positive cells that colocalize CB1 cannabinoid receptors.
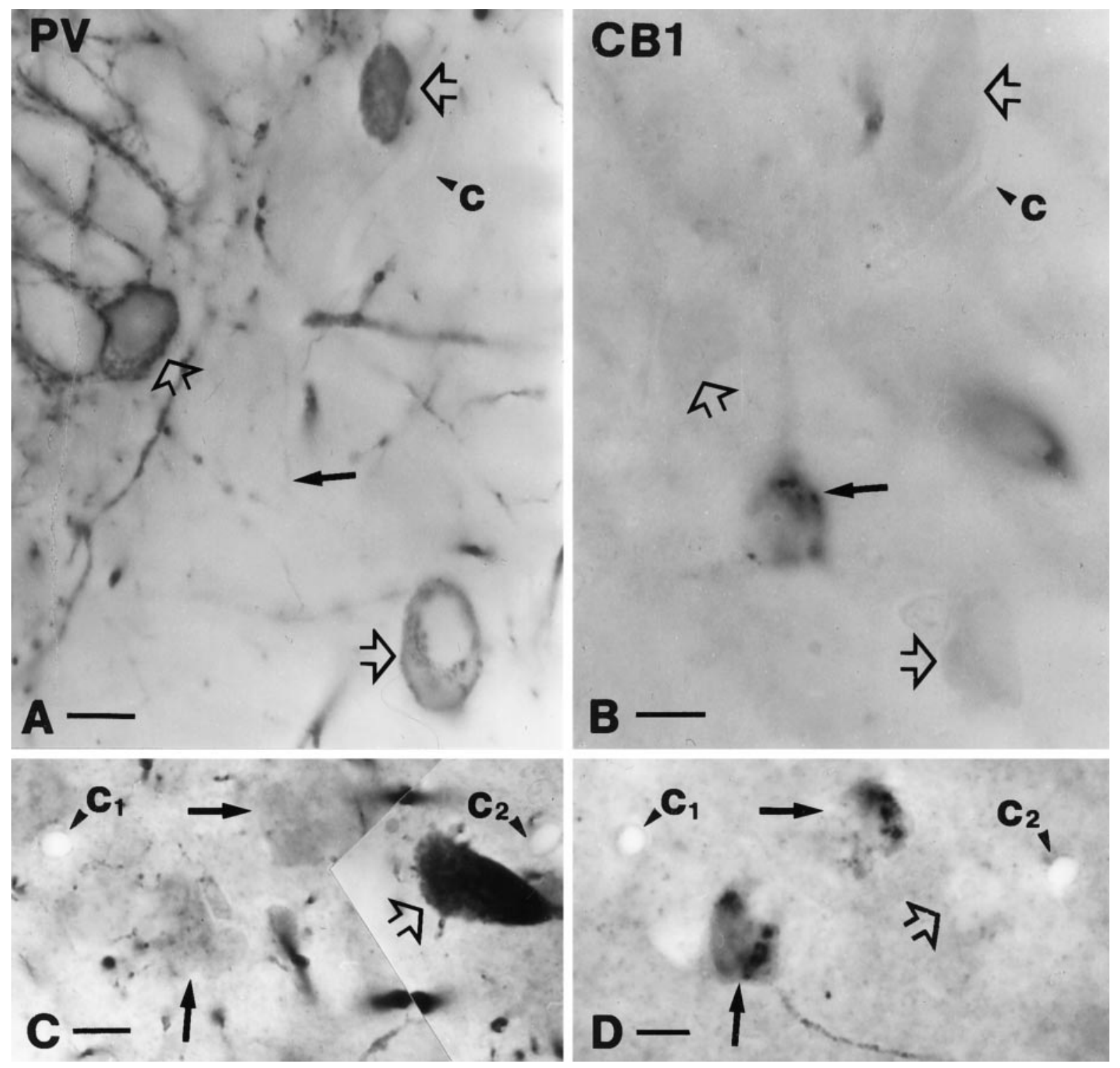

Figure 2. Parvalbumin-positive cells represent a subpopulation of perisomatic inhibitory interneurons that does not contain CB1-immunoreactivity. $A$, $B$, Parvalbumin-positive neurons (open arrows in $A$ ) in the dentate gyrus never showed CB1-immunoreactivity. The other halves of the somata, negative for CB1, are labeled by open arrows in B. Filled arrows depict a CB1-immunoreactive cell body in $B$ and its PV-negative half in $A$. $C$, $D$, Parvalbumin-positive neurons (open arrow in $C$ ) proved to be CB1-negative (open arrow on $D$ ) in stratum pyramidale of the CA1 subfield. Filled arrows depict CB1-immunoreactive but parvalbumin-negative somata. Capillaries labeled by $c_{1-2}$ served as landmarks and confirmed the localization of the halved cell bodies. $P V$, Parvalbumin; $C B 1, \mathrm{CB} 1$ cannabinoid receptor. Scale bars, $10 \mu \mathrm{m}$.

technique of Kosaka et al. (1985), 130 PV-immunoreactive neurons were examined from all subfields of the hippocampus, and only six were positive for CB1 (4.6\%) (Fig. 2). In contrast, nearly all CCK-immunoreactive neurons contained this receptor
(96.9\%; $n=97$ ) (Fig. 3). To determine whether CCK-containing cells represent only a subpopulation of CB1-expressing cells or the two interneuron populations completely overlap, 97 CB1positive cells were examined; 83 of them proved to be positive for 


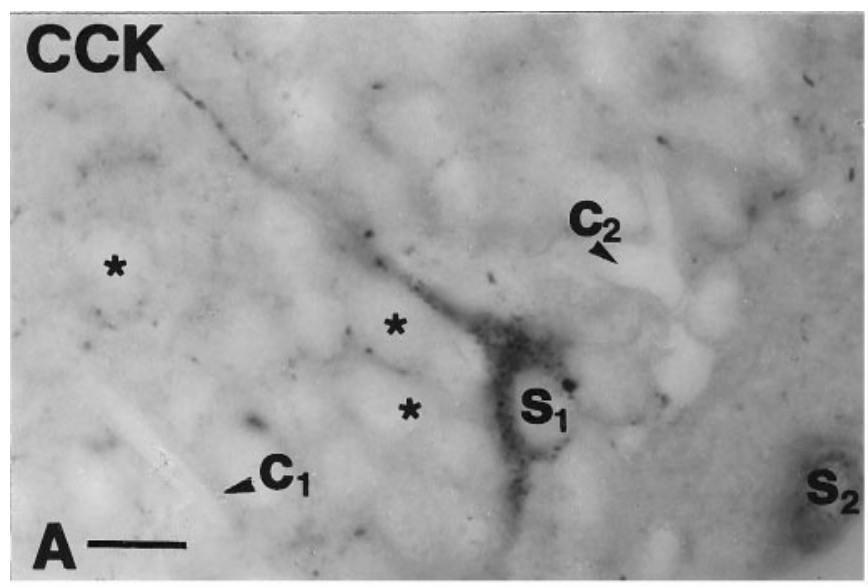

\section{CB1}
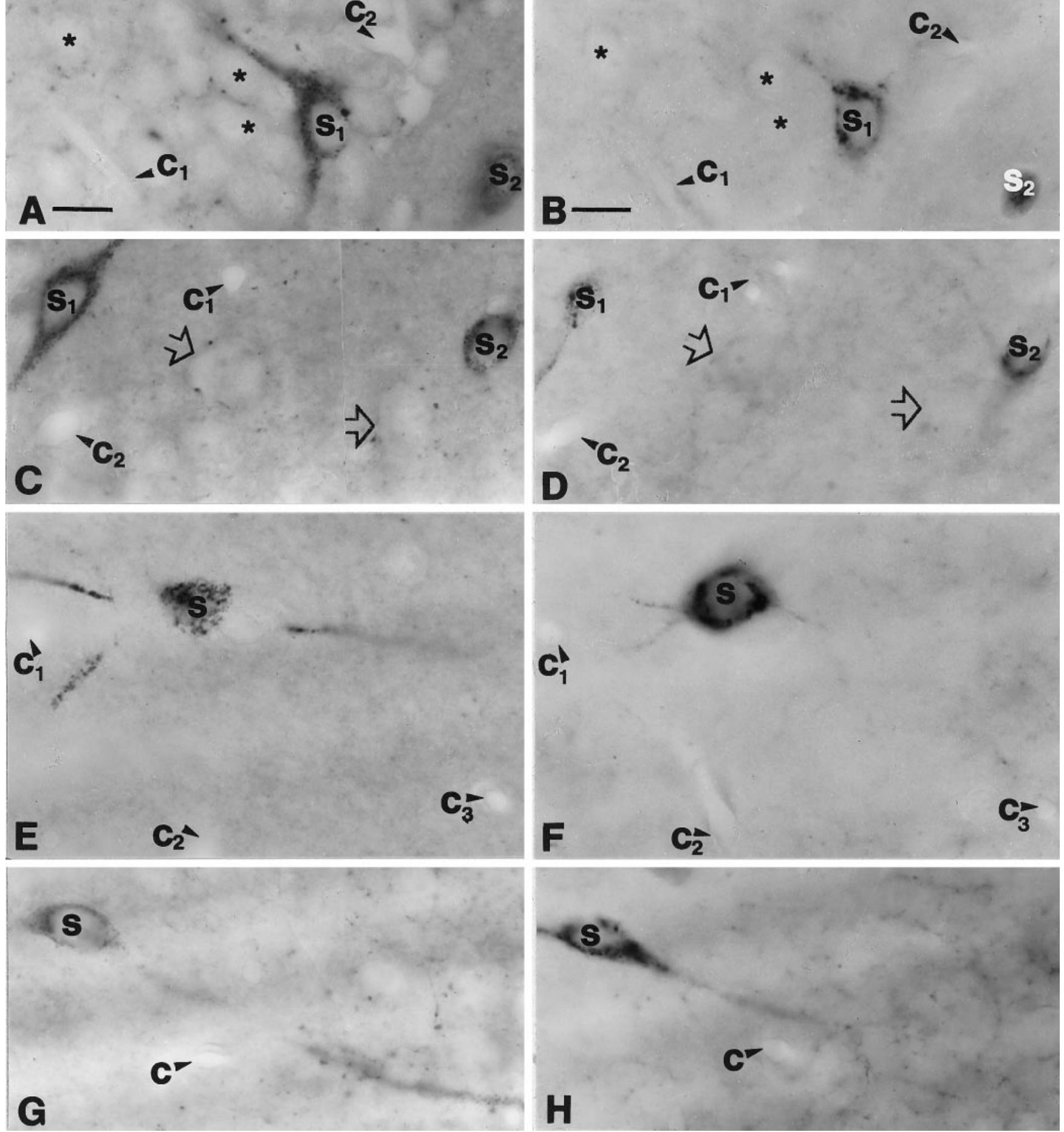

Figure 3. Cholecystokinin-containing interneurons express CB1 cannabinoid receptor in the hippocampus. $A$, $B$, A CCK-immunoreactive pyramidallike basket cell $\left(S_{1}\right)$ in the dentate gyrus contains CB1-immunoreactivity. Granule cells $(*)$ were negative for both markers. $C, D$, In the CA3 subfield large somata with thick proximal dendrites $\left(S_{1}\right)$ and smaller multipolar cells $\left(S_{2}\right)$ were positive for both CCK and CB1. Open arrows indicate double-negative cell bodies. $E-H$, These two morphological types colocalized CCK and CB1 in the CA1 subfield as well. A multipolar CCK-positive cell $(S$ in $E)$ in stratum radiatum is cut in half on the surface of the section. The same cell $(S$ in $F)$ shows CB1-immunoreactivity in the adjacent section. Three primary dendrites are also seen to continue in the adjacent section. $G, H$, A large bitufted neuron at the border of strata oriens and pyramidale is shown to be double-labeled. Capillaries labeled by $c_{1-3}$ serve as landmarks to confirm precise alignment. $C C K$, Cholecystokinin; $C B 1, \mathrm{CB} 1$ cannabinoid receptor. Scale bars (shown in $A$ and $B$ for $A-H$ ): $15 \mu \mathrm{m}$. 
this neuropeptide $(85.6 \%)$. Taken together, these results demonstrate that CB1 is expressed mostly by a specific subtype of perisomatic hippocampal interneurons, the CCK-containing basket cells.

\section{Subcellular localization of CB1 cannabinoid receptors in hippocampal interneurons}

To answer the question of whether cannabinoids act primarily presynaptically on axon terminals or postsynaptic effects on cell bodies and dendrites of interneurons are also possible, the precise subcellular localization of the receptor was determined. Using $\mathrm{DAB}$ or DAB-Ni as chromogen, the reaction product is localized in specific cytoplasmic organelles in the somata (Fig. 4A). However, the diffusible nature of DAB makes it unsatisfactory to identify the precise subcellular localization of the receptor. Hence we used pre-embedding immunogold staining to explore the subcellular distribution of CB1. At the light microscopic level the immunopositive sites usually showed a patchy distribution similar to the immunoperoxidase labeling; large granules were observed mostly in the perinuclear cytoplasm of interneurons (Figs. 2D, 3B). Correlated light and electron microscopy of selected CB1-positive somata showed that these granules correspond to clusters of silver-intensified gold particles localized in the Golgi apparatus (Fig. 4B) and in the rough endoplasmic reticulum (Fig. 4C). The gold particles were usually observed inside the cisternae, but labeling outside their membrane was also found occasionally. Consistent labeling on the somadendritic plasma membrane of these interneurons was not observed.

One of the most striking features of CB1-immunostaining is the localization in large numbers of basket terminals around the principal cell somata in the CA3 and CA1 subfields (Fig. 1B,C). Therefore, the possible presynaptic localization of CB1 on these boutons was examined at the electron microscopic level. Gold particles were selectively localized on the extracellular side of the plasma membrane of axon terminals (Fig. $4 D_{1-3}$ ). This was expected, because the antibody used in this study was raised against the N-terminal segment of the receptor, which is an extracellular domain for G-protein-coupled receptors. Those boutons containing the receptor gave rise to symmetric synapses onto their postsynaptic targets in strata oriens, pyramidale, and radiatum. However, not all boutons with symmetric synapses were labeled by CB1. The CB1-immunoreactive terminals contained densecore vesicles in several cases (see Fig. $6 B_{2-3}$ ). Preterminal axon segments were also labeled, but they carried fewer gold particles. CB1 was predominantly localized extrasynaptically around the boutons (Fig. $4 D_{1-3}$ ) at variable distances from the synaptic active zone. Gold particles could be found perisynaptically in some cases (Fig. $5 A_{3}$ ), but they were more common along the back of the terminals, i.e., away from the synaptic side. Although postembedding immunogold methods could provide a higher resolution of the distribution, these results reveal that CB1 is localized in a key position to modulate GABA release directly from axon terminals.

\section{CB1 cannabinoid receptors are localized presynaptically on cholecystokinin-containing but not on parvalbumin-immunoreactive axon terminals}

Although we have shown that CB1 is present in CCK- but not in PV-containing interneuron somata, it does not necessarily mean a similar selectivity at the level of terminals. For example, type 2 muscarinic receptor immunoreactivity was not observed in the somata of PV-positive neurons; nevertheless, their terminals carried this receptor type (Hájos et al., 1998). To investigate colo- calization in basket cell boutons, double-immunostaining has been performed at the electron microscopic level. More than 100 randomly selected CCK-immunoreactive boutons were examined in the CA3 and CA1 subfields, and most were found to carry the CB1 receptor (Fig. 5, Table 2). An unequivocal identification of all double-labeled boutons is impossible here, because falsenegativity for CB1 increases in an unpredictable fashion when moving deeper into the vibratome sections with the ultrathin series. Thus, to provide a correct quantification, an "unidentified" category has been introduced for boutons with an inconsistent labeling (see Materials and Methods). CCK-negative but CB1positive boutons were not found. The CCK/CB1 doubleimmunostained boutons always gave rise to symmetric synapses and contained dense-core vesicles in most but not all cases (Fig. 6 ). The majority of boutons were found in stratum pyramidale and innervated principal cell somata, but dendrites were also among the postsynaptic targets in strata oriens and radiatum.

In contrast, only a minor proportion $(<4 \%)$ of $\mathrm{PV}$ immunoreactive boutons carried the $\mathrm{CB} 1$ receptor both in the CA3 and CA1 subfields (Fig. 6). In several cases, the gold-labeled CB1-positive/PV-negative boutons were localized adjacent to the $\mathrm{PV}$-positive/CB1-negative boutons, confirming that poor penetration was not the reason for the lack of CB1-staining in PV-positive boutons.

\section{Modulation of hippocampal $\left[{ }^{3} \mathrm{H}\right] \mathrm{GABA}$ release by cannabinoids}

The presence of CB1 receptors on GABAergic axon terminals suggests that cannabinoids modulate GABA release. This was investigated by in vitro release experiments. After $60 \mathrm{~min}$, spontaneous $\left[{ }^{3} \mathrm{H}\right] \mathrm{GABA}$ efflux was $0.189 \pm 0.009 \%(n=12)$ and was fairly constant during the subsequent sample collection periods. Electrical field stimulation ( $35 \mathrm{~V}, 3 \mathrm{msec}, 2 \mathrm{~Hz}, 360$ pulses) elicited a rapidly increasing tritium outflow $\left(\mathrm{S}_{1}=0.30 \pm 0.03 \%\right.$, $n=12$ ), which reached its peak 3 min after stimulation and returned to the baseline level in the next $6 \mathrm{~min}$ (Fig. 7A). The increase in tritium outflow caused by the second stimulation period $\left(\mathrm{S}_{2}\right)$ was comparable to that elicited by the first stimulation $\left(\mathrm{S}_{1}\right)$ in control experiments, yielding $\mathrm{S}_{2} / \mathrm{S}_{1}$ ratios close to 1 $(1.01 \pm 0.11, n=12)$. Perfusion of the slices with the sodium channel inhibitor tetrodotoxin $(1 \mu \mathrm{M})$ almost completely prevented stimulation-evoked $\left[{ }^{3} \mathrm{H}\right] \mathrm{GABA}$ efflux, indicating that action potential-mediated release was measured by this paradigm $\left(\mathrm{S}_{2} / \mathrm{S}_{1}=0.15 \pm 0.1, n=6, p<0.001\right.$, vs control). In preliminary experiments, high-frequency stimulation $(10 \mathrm{~Hz})$ delivering the same number of pulses was shown to result in a greater increase in tritium efflux; however, the $S_{2} / S_{1}$ ratio in this case was considerably smaller. Therefore, in all subsequent experiments, $2 \mathrm{~Hz}$ stimulation frequency was used.

The synthetic cannabinoid receptor agonist WIN 55,212-2 $(0.01-3 \mu \mathrm{M})$ reduced electrical field stimulation-induced $\left[{ }^{3} \mathrm{H}\right] \mathrm{GABA}$ release in a concentration-dependent manner (Fig. $7 B$ ), with an $\mathrm{EC}_{50}$ value of $0.041 \mu \mathrm{M}$. The maximal effect of W IN $55,212-2$ on evoked $\left[{ }^{3} \mathrm{H}\right] \mathrm{GABA}$ was obtained at $1 \mu \mathrm{M}$ concentration: the $\mathrm{S}_{2} / \mathrm{S}_{1}$ ratio was $0.53 \pm 0.06(n=7, p<0.01$ vs control $)$, which corresponds to $\sim 48 \%$ inhibition (Fig. $7 A, B$ ). When WIN 55,212-2 was applied in higher concentration (3 $\mu \mathrm{M})$, further increase in inhibition was statistically insignificant (Fig. $7 B$ ). The basal outflow of $\left[{ }^{3} \mathrm{H}\right] \mathrm{GABA}$ did not change in the presence of WIN 55,212-2. The $\mathrm{R}_{2} / \mathrm{R}_{1}$ ratios were $0.84 \pm 0.04$ and $0.92 \pm$ 0.08 in the absence and presence of $1 \mu \mathrm{M}$ WIN 55,212-2 ( $n=7$ and $12, p>0.05)$, respectively. 


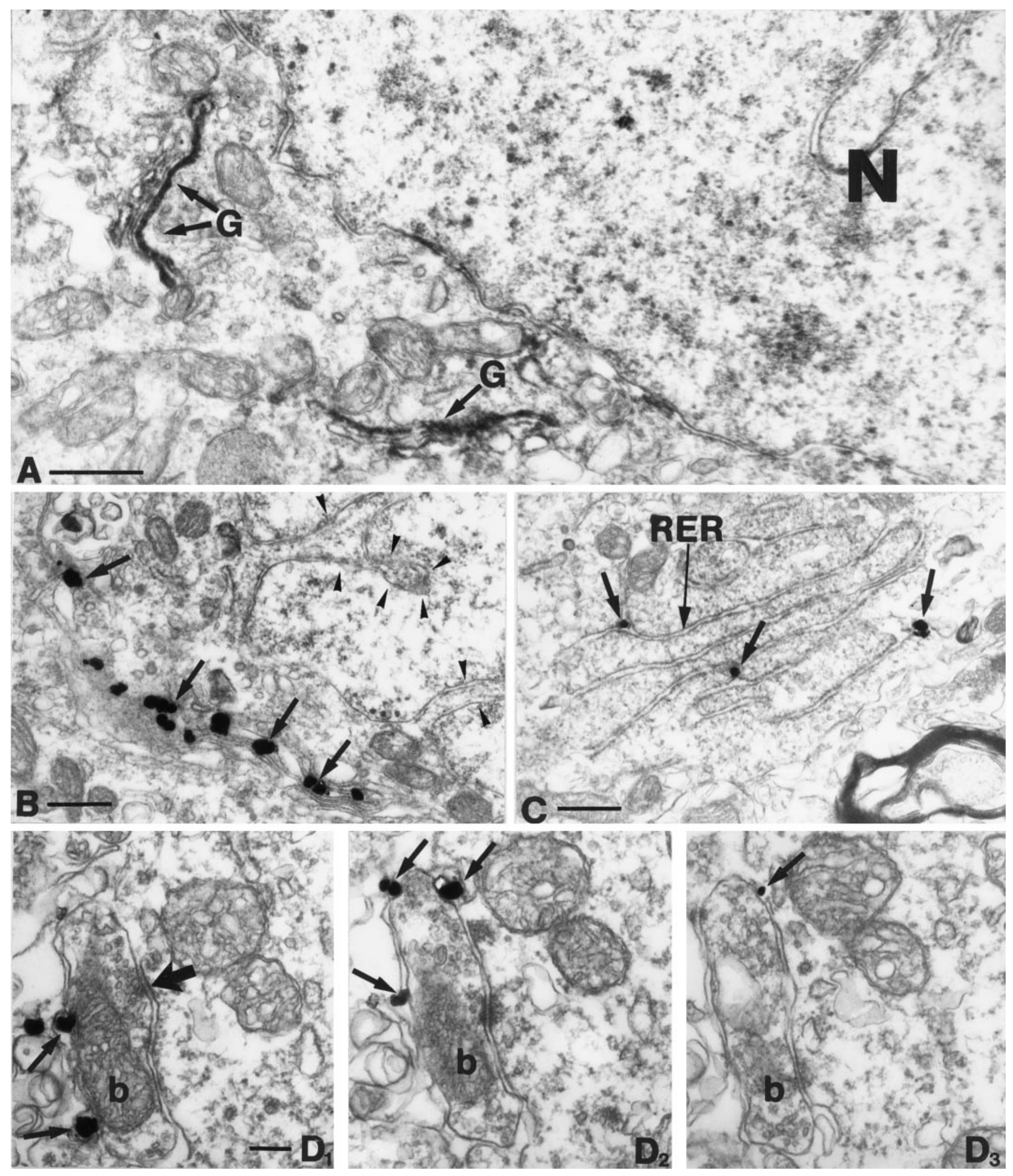

Figure 4. A, Low-power electron micrograph of a CB1-immunoreactive cell body. In this experiment, DAB was used as chromogen. Note the rather selective localization of the DAB precipitate in the Golgi apparatus $(G) . B, C$, Immunogold labeling confirmed at a higher resolution that $\mathrm{CB} 1$ is localized in the Golgi apparatus (arrows in $B$ ) and in the rough endoplasmic reticulum (RER, arrows in $C$ ). Arrowheads in $B$ label the invaginated nucleus, which further confirms that $\mathrm{CB} 1$ is expressed by interneurons. $D_{1-3}$, In stratum pyramidale, gold particles representing CB1-immunoreactivity were found on the plasma membrane of axon terminals (arrows), on the side facing the extracellular space. This confirms that the antibody used in this study was raised against the N-terminal domain of CB1, which is located extracellularly. Moreover, this figure shows that CB1 is localized presynaptically on boutons of inhibitory neurons $(b)$, because these boutons formed exclusively symmetrical synapses with their targets (thick arrow). $N$, Nucleus; $G$, Golgi apparatus; $R E R$, rough endoplasmic reticulum. Scale bars: $A-C, 0.5 \mu \mathrm{m} ; D_{1-3}, 0.1 \mu \mathrm{m}$. 


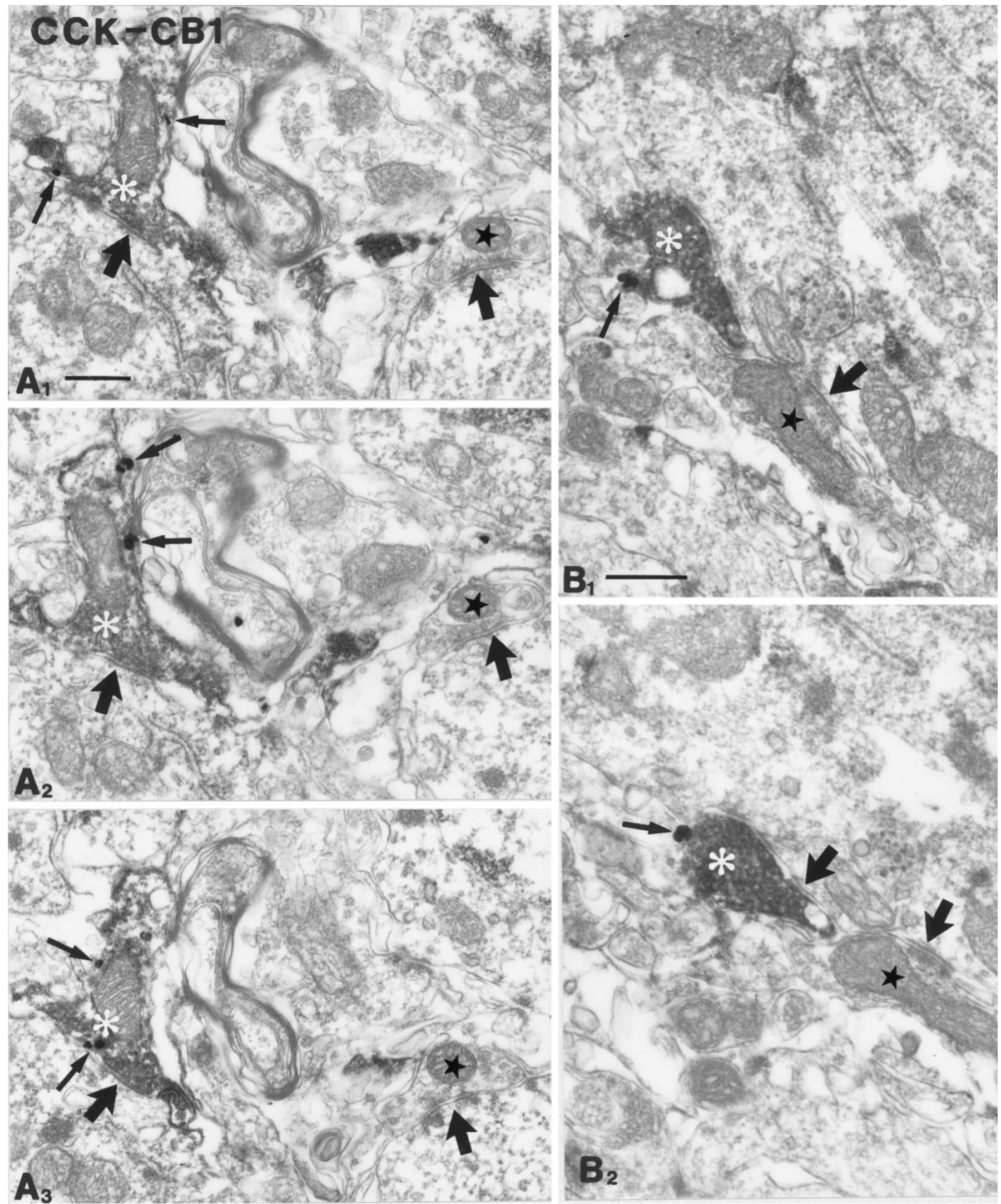

Figure 5. CB1 cannabinoid receptors are localized presynaptically on cholecystokinin-immunoreactive axon terminals. Most of the CCK-positive boutons (white asterisks; diff use DAB end-product) were found to be positive for CB1 (gold particles labeled by thin arrows). The serial sections in $A_{1-3}$ were taken from the CA1 subfield; those in $B_{1-2}$ derive from CA3. These terminals formed symmetrical synapses mainly on somata and proximal dendrites of their targets. Adjacent boutons (stars), which were negative for both markers, also formed symmetrical synapses. Thick arrows indicate symmetrical, probably GABAergic synapses. $C C K$, Cholecystokinin; $C B 1$, CB1 cannabinoid receptor. Scale bars: $A, B, 0.4 \mu \mathrm{m}$. 
Table 2. Occurrence of CB1 on CCK- or PV-immunoreactive boutons

\begin{tabular}{|c|c|c|c|c|c|c|c|}
\hline & \multicolumn{3}{|l|}{$\mathrm{CCK}$} & & \multicolumn{3}{|l|}{ PV } \\
\hline & Positive & Negative & Unidentified & & Positive & Negative & Unidentified \\
\hline $\mathrm{CA} 1(n=50)$ & $76.0 \%$ & $6.0 \%$ & $18.0 \%$ & CA1 $(n=25)$ & $0.0 \%$ & $88.0 \%$ & $12.0 \%$ \\
\hline $\mathrm{CA} 3(n=52)$ & $82.7 \%$ & $3.8 \%$ & $13.5 \%$ & CA3 $(n=26)$ & $7.7 \%$ & $80.7 \%$ & $11.6 \%$ \\
\hline Total $(n=102)$ & $79.4 \%$ & $4.9 \%$ & $15.7 \%$ & Total $(n=51)$ & $3.9 \%$ & $84.3 \%$ & $11.8 \%$ \\
\hline
\end{tabular}

In the electron microscopic double-labeling experiment, CCK or PV immunoreactivity was visualized by immunoperoxidase reaction $(\mathrm{DAB})$, and $\mathrm{CB} 1$ cannabinoid receptors by pre-embedding immunogold staining.

The effect of WIN 55,212-2 (1 $\mu \mathrm{M})$ was also examined under the blockade of NMDA and non-NMDA type glutamate receptor antagonists, i.e., in the presence of AP-5 (10 $\mu \mathrm{M})$ and CNQX (10 $\mu \mathrm{M})$. The inhibitory action of WIN 55,212-2 on stimulationinduced $\left[{ }^{3} \mathrm{H}\right] \mathrm{GABA}$ outflow remained unaffected under these conditions (Fig. 7C).

When the slices were perfused with SR141716A (1 $\mu \mathrm{M})$, the CB1 cannabinoid receptor antagonist, $18 \mathrm{~min}$ before the second stimulation period, neither the basal nor the stimulation-induced outflow of tritium was altered significantly $\left(\mathrm{R}_{2} / \mathrm{R}_{1}=0.81 \pm 0.04\right.$, $\mathrm{S}_{2} / \mathrm{S}_{1}=1.22 \pm 0.28, n=6, p>0.05$ vs control). In the presence of SR141716A, WIN 55,212-2 was ineffective in reducing field stimulation-evoked $\left[{ }^{3} \mathrm{H}\right] \mathrm{GABA}$ efflux, resulting in $\mathrm{S}_{2} / \mathrm{S}_{1}$ ratios similar to control (Fig. $7 C$ ).

Because previous data indicated (Maneuf et al., 1996) that WIN 55,212-2 also has a potential effect on GABA uptake, and our superfusion medium was not routinely supplemented with GABA uptake blockers, the effect of WIN 55,212-2 was also evaluated on the uptake of $\left[{ }^{3} \mathrm{H}\right] \mathrm{GABA}$. W IN 55,212-2 $(1 \mu \mathrm{M}) \mathrm{did}$ not change the uptake of GABA in our system. The tritium uptake was $1.65 \pm 0.3 \times 10^{6}$ and $1.5 \pm 0.13 \times 10^{6} \mathrm{~Bq} / \mathrm{gm}$ in the absence and presence of WIN 55212-2 ( $n=6, p>0.05)$, respectively; therefore the effect of WIN 55,212-2 on the stimulationinduced outflow of GABA reflects a change in the release process itself.

\section{DISCUSSION}

The present study describes the precise cellular and subcellular distribution of CB1 cannabinoid receptors in interneurons of the rat hippocampus and the effects of $\mathrm{CB} 1$ activation on GABA release. The results provide direct morphological evidence for the presynaptic localization of CB1 receptor on nerve terminals belonging to a specific subpopulation of hippocampal GABAergic interneurons, namely the CCK-containing basket cells. Thus, by reducing GABA release from basket cell terminals, both endogenous and exogenous CB1 ligands likely interfere with network oscillations known to be governed by these cells. Interestingly, the other perisomatic inhibitory cell type, the PV-containing basket cells, did not contain the receptor, providing further evidence for the functional diversity between the CCK- and PV-positive interneurons.

\section{Subcellular distribution of CB1 cannabinoid receptor}

CB1-immunoreactivity was found in two discrete subcellular domains of hippocampal interneurons by immunogold labeling. A patchy and granular immunostaining was present inside the somata and most proximal dendrites at the light microscopic level, corresponding to rough endoplasmic reticulum and the Golgi apparatus. These results suggest that the polyclonal antibody used in the present study recognizes the newly synthesized CB1 receptor protein even in the Golgi apparatus. The lack of immuno- staining on the membrane of the dendritic tree or soma suggests that $\mathrm{CB} 1$ does not mediate postsynaptic effects on the somadendritic compartment of hippocampal interneurons. This is in sharp contrast to immunostaining for several other receptor types, which typically outline the entire dendritic arbor of certain hippocampal interneuron populations (Baude et al., 1993; Gao and Fritschy, 1994; Acsády et al., 1997; Hájos et al., 1998).

Axonal immunostaining for CB1 was very intense in the hippocampus in large boutons forming baskets around the principal cells. At the electron microscopic level CB1 receptors were located in the membrane of boutons, which always formed symmetric synapses. Gold particles were found both extrasynaptically and perisynaptically but not subsynaptically. However, the localization of CB1 presynaptically within the active zones cannot be ruled out, because the negative staining may be caused by the lack of antibody penetration into the dense matrix of the synaptic cleft. Regardless of the precise localization of CB1 along the axon terminal membrane, these receptors could be easily reached by endogenous cannabinoids potentially released from postsynaptic sites (Stella and Piomelli, 1998), (e.g., from the cell bodies and proximal dendrites of pyramidal cells). Taken together, these results suggest that cannabinoids exert their modulatory effects on the GABAergic systems of the hippocampus by a presynaptic rather than a postsynaptic mechanism.

\section{Modulation of hippocampal GABA release by cannabinoids}

Recent studies suggest that physiological effects of endogenous and exogenous cannabimimetics are mainly mediated by presynaptic inhibitory mechanisms in the substantia nigra pars reticulata, cerebellum, and striatum (Chan et al., 1998; Lévenes et al., 1998; Szabó et al., 1998). On the basis of the present study demonstrating that $\mathrm{CB} 1$ in the hippocampus is predominantly localized on axon terminals of a specific CCK-containing, GABAergic basket cell type, the major target of cannabinoid action seems to be GABA (and/or CCK) release. In our experiments the aminoalkylindole-type cannabinoid receptor agonist WIN 55,212-2 (D’Ambra et al., 1992) reduced dose-dependently the electrical field stimulation-induced $\left[{ }^{3} \mathrm{H}\right] \mathrm{GABA}$ release, indicating that $\mathrm{CB} 1$ cannabinoid receptors modulate GABA release in the hippocampus. That WIN 55,212-2 inhibits GABA release via $\mathrm{CB} 1$ receptors is supported by the following arguments. (1) WIN 55,212-2 reduced GABA outflow over a concentration range (0.01-3 $\mu \mathrm{M})$, compatible with $\mathrm{CB} 1$ receptor activation (D’Ambra et al., 1992; Shen and Thayer, 1998; Szabó et al., 1998), and the $\mathrm{EC}_{50}$ value is similar to that obtained in other release studies investigating the effect of WIN 55,212-2 on the release of $\left[{ }^{3} \mathrm{H}\right]$ acetylcholine and $\left[{ }^{3} \mathrm{H}\right]$ noradrenaline (Gifford and Ashby, 1996; Schlicker et al., 1997). (2) It selectively decreased the stimulation-evoked efflux of $\left[{ }^{3} \mathrm{H}\right] \mathrm{GABA}$ but not the basal outflow. (3) Its inhibitory effect was prevented by the selective CB1 


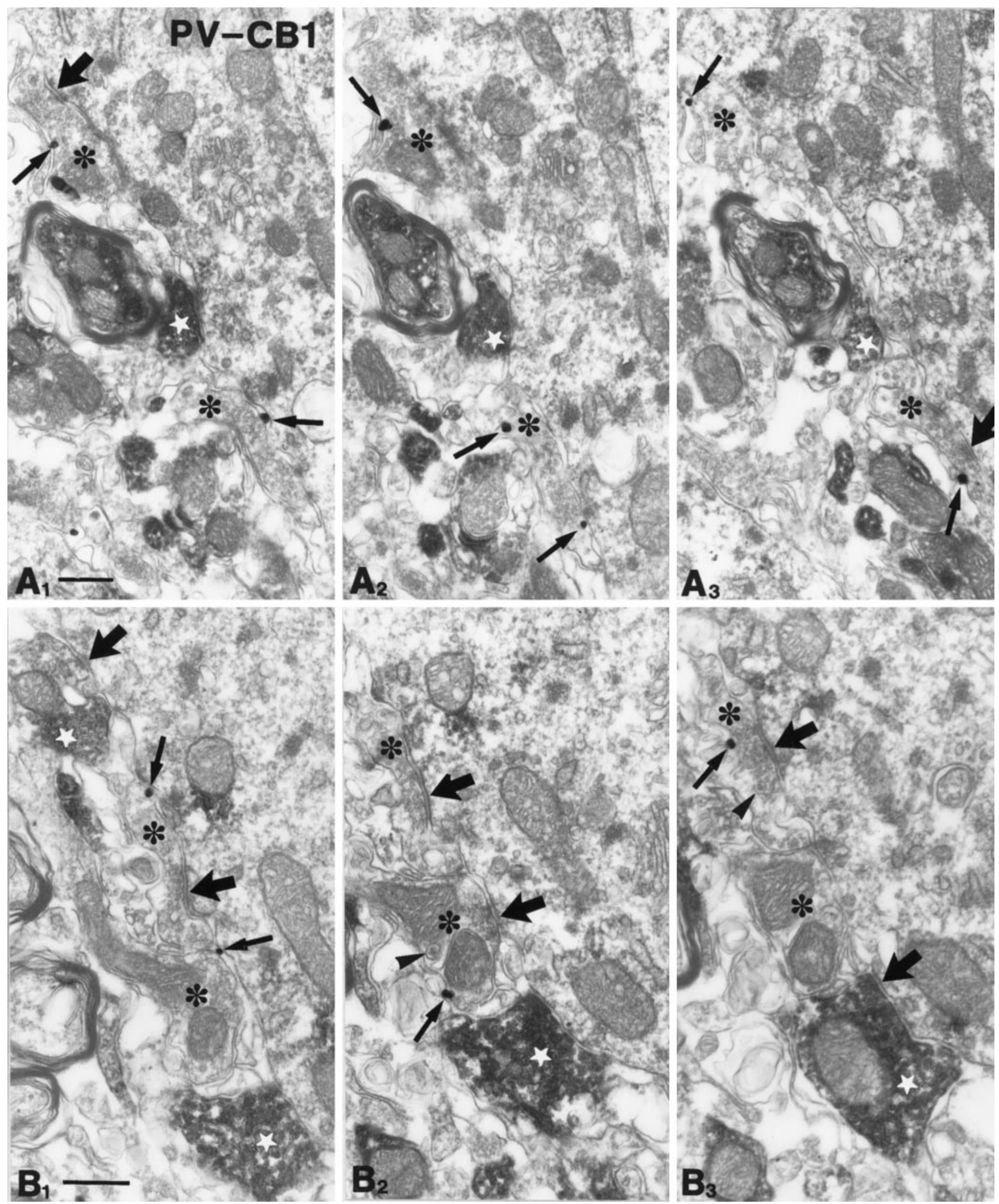

Figure 6. Parvalbumin-immunoreactive axon terminals are negative for CB1 cannabinoid receptors. Parvalbumin-immunoreactive boutons (diff use DAB precipitate; white stars) are shown from stratum pyramidale of the CA1 $\left(A_{1-3}\right)$ and CA3 $\left(B_{1-3}\right)$ subfields, forming symmetrical synapses with their targets. Several CB1-positive (gold particles labeled by arrows) axon terminals $\left({ }^{*}\right)$ were found nearby, but CB1 and PV did not colocalize to the same boutons. These CB1-positive boutons contained several dense-core vesicles (arrowheads), which probably contain the neuropeptide cholecystokinin. These findings further confirm that the two basket cell populations are distinct regarding their presynaptic receptors. Thick arrows label symmetrical synapses. Thin arrows depict gold particles representing CB1 receptor immunoreactivity. $P V$, Parvalbumin; $C B 1$, CB1 cannabinoid receptor. Scale bars: A, $B, 0.4 \mu \mathrm{m}$. 


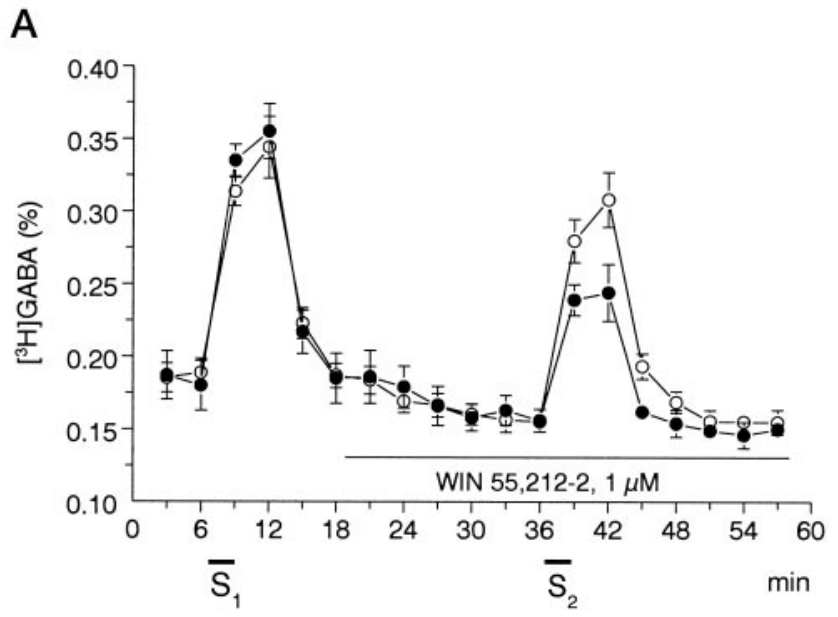

B

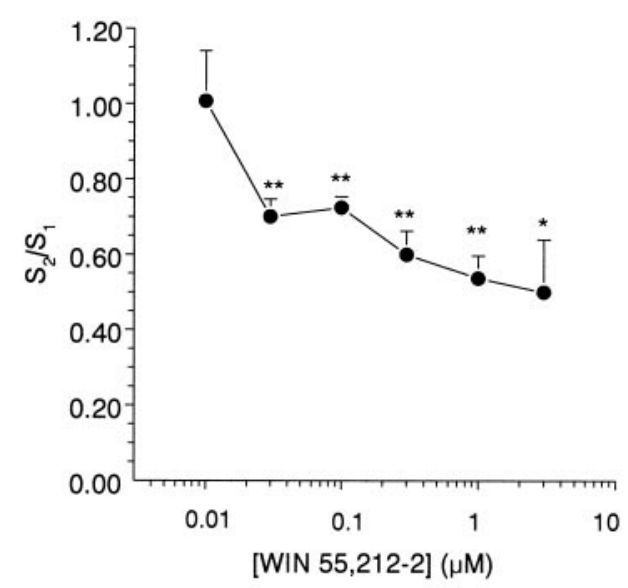

C
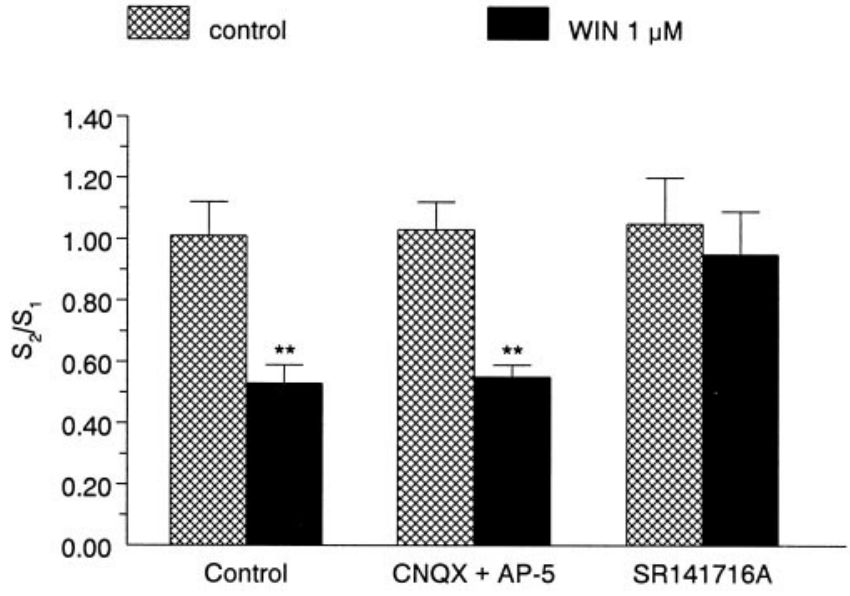

Figure 7. A, A cannabinoid agonist, $1 \mu \mathrm{M}$ WIN55,212-2, inhibits electrically evoked $\left[{ }^{3} \mathrm{H}\right] \mathrm{GABA}$ release from rat hippocampal slices. The slices were superfused for $60 \mathrm{~min}$ at a rate of $0.7 \mathrm{ml} / \mathrm{min}$. After the preperfusion period, 3 min samples were collected and assayed for radioactivity. $\left[{ }^{3} \mathrm{H}\right] \mathrm{GABA}$ release was significantly increased in response to electrical field stimulation $\left(S_{1}, S_{2}\right)$. Open circles represent control experiments; filled circles show experiments when WIN 55,212-2 was present during the second stimulation period $\left(S_{2}\right)$. The release of $\left[{ }^{3} \mathrm{H}\right] \mathrm{GABA}$ was expressed as fractional release (\%; for calculation see Materials and Methods). The values show the mean \pm SEM of 7-12 identical experiments. $B$, Concentration dependence of the effect of WIN55,212-2 on stimulation-induced receptor antagonist SR141716A $(1 \mu \mathrm{M})$ (Rinaldi-Carmona et al., 1994). (4) A number of earlier studies indicate that WIN 55,212-2 does not act on other neurotransmitter receptor types in this concentration range (Ward et al., 1990; Pacheco et al., 1991; Compton et al., 1992; Jansen et al., 1992; Pertwee, 1997). Nevertheless, one has to consider other possible routes whereby WIN 55,212-2 might interfere with the stimulation-evoked outflow of $\left[{ }^{3} \mathrm{H}\right] \mathrm{GABA}$.

In fact, it has been reported that a high concentration of cannabinoids reduces $\left[{ }^{3} \mathrm{H}\right] \mathrm{GABA}$ uptake in the globus pallidus (Maneuf et al., 1996). We did not observe any significant effect of WIN 55,212-2 on $\left[{ }^{3} \mathrm{H}\right] \mathrm{GABA}$ uptake; higher concentrations of this agonist are likely to be required for such an effect. Even if WIN 55,212-2 reduced GABA uptake, an increase rather than a decrease in both the basal and stimulation-evoked outflow would be expected.

Cannabinoid receptor agonists were shown to inhibit glutamatergic neurotransmission in cultured hippocampal neurons (Shen et al., 1996), thus one might assume that the decrease in $\left[{ }^{3} \mathrm{H}\right] \mathrm{GABA}$ release in response to WIN 55,212-2 application is caused by a reduced excitatory drive of GABAergic neurons. However, WIN 55,212 (1 $\mu \mathrm{M})$ elicited a similar decrease in evoked tritium release when glutamatergic transmission was blocked by the NMDA and non-NMDA-type glutamate receptor antagonists AP-5 and CNQX, showing that its effect is not caused by a decrease in excitatory transmission.

Because cannabinoids are able to modulate the release of noradrenaline and acetylcholine from hippocampus (Gifford et al., 1997; Schlicker et al., 1997; Gessa et al., 1998), another possible explanation of the WIN 55,212-2-induced reduction of $\left[{ }^{3} \mathrm{H}\right] \mathrm{GABA}$ release might be the involvement of presynaptic mechanism controlling GABA release via other transmitter systems. Again, the release of $\left[{ }^{3} \mathrm{H}\right] \mathrm{GABA}$ should have been increased rather than reduced by WIN 55,212-2 in the case of disinhibition of muscarinic receptors. Therefore, the most likely conclusion remains that WIN 55,212-2 inhibited GABA efflux via a direct action on CB1 receptors localized on basket cell terminals. Electrophysiological studies (Vardaris and Weisz, 1977; Kujtan et al., 1983; Paton et al., 1998) found that cannabinoids enhance the evoked population spikes and impair paired-pulse inhibition in the CA1 region, also consistent with a reduction in perisomatic inhibition. In contrast, Shen et al. (1996) using hippocampal cultures reported that WIN 55,212-2 did not affect

$\leftarrow$

$\left[{ }^{3} \mathrm{H}\right]$ GABA release from rat hippocampal slices. The cannabinoid receptor agonist WIN 55,212-2 was applied to the slices by perfusion according to the protocol shown in $A$ in different concentrations ranging from 0.01 to $3 \mu \mathrm{M}$, and its effect on stimulation-evoked $\left[{ }^{3} \mathrm{H}\right] \mathrm{GABA}$ outflow was expressed as $\mathrm{S}_{2} / \mathrm{S}_{1}$ ratios (for calculation, see Materials and Methods). The values show the mean \pm SEM of 7-12 identical experiments. Asterisks represent significant differences from the control $\mathrm{S}_{2} / \mathrm{S}_{1}$ ratio, measured in the absence of drugs $(1.01 \pm 0.11, n=12)$, calculated by ANOVA followed by the Dunnett test $\left({ }^{*} p<0.05,{ }^{* *} p<0.01\right)$. $C$, Interaction of the effect of WIN55,212-2 on stimulation-induced $\left[{ }^{3} \mathrm{H}\right] \mathrm{GABA}$ release with glutamate receptor antagonists AP-5 and CNQX and with the CB1 receptor antagonist SR141716A in rat hippocampal slices. The effect of drugs on stimulation-induced release of $\left[{ }^{3} \mathrm{H}\right] \mathrm{GABA}$ was expressed as $\mathrm{S}_{2} / \mathrm{S}_{1}$ ratio, measured in the absence (cross-hatched bars) and presence of WIN55,212-2 (black bars). The perfusion with WIN55,212-2 (1 $\mu \mathrm{M})$ started $18 \mathrm{~min}$ before $\mathrm{S}_{2}$ and continued thereafter, whereas AP-5 $(10 \mu \mathrm{M})$, CNQX $(10 \mu \mathrm{M})$, and SR141716A $(1 \mu \mathrm{M})$ were perfused from $15 \mathrm{~min}$ before $\mathrm{S}_{1}$. Data show the mean \pm SEM of 6-12 identical experiments. Asterisks represent significant difference from respective controls $\left({ }^{* *} p<\right.$ 0.01 calculated by Student's $t$ test). 
GABAergic synaptic transmission. However, it is likely that the synaptic organization and receptor distribution are not maintained in these dispersed cultures.

In contrast to other neurotransmitter release studies (Gifford and Ashby, 1996; Schlicker et al., 1997), SR141716A, when added alone, did not change significantly the stimulation-evoked outflow of GABA under our experimental conditions. This result argues against a tonic inhibitory control of GABA release by endogenously released cannabinoids in the hippocampal slice.

\section{Selective effect of cannabinoids on cholecystokinin- containing but not on other types of basket cells suggests functional specificity}

The most likely mechanism of presynaptic cannabinoid effects is that they inhibit $\mathrm{N}$ - and $\mathrm{P} / \mathrm{Q}$-type $\mathrm{Ca}^{2+}$ channels or activate potassium conductances (Caulfield and Brown, 1992; Mackie and Hille, 1992; Deadwyler et al., 1995; Mackie et al., 1995). Either of these actions may explain the inhibition of GABA release in the hippocampus found in the present study. Because CB1 was present only on CCK-immunoreactive basket cell terminals, understanding the role of this perisomatic interneuron type in the control of hippocampal networks may help to comprehend the behavioral and network effects of cannabinoids. Perisomatic inhibitory interneurons inhibit $\mathrm{Na}^{+}$-dependent action potentials (Buhl et al., 1994; Miles et al., 1996) and may play an important role in rhythmic synchronization of large ensembles of principal cells (Cobb et al., 1995; Ylinen et al., 1995). These oscillatory events likely account for a major component of theta and gamma activity (Soltész and Deschenes, 1993; Ylinen et al., 1995; Penttonen et al., 1998). Therefore, cannabinoids may disrupt the synchronization of principal cells at slow and fast frequencies by inhibition of GABA release from basket cells and thereby desynchronize theta activity as shown decades ago (Lipparini et al., 1969; Willinsky et al., 1973; Constoe et al., 1975; Sagratella et al., 1986). Theta activity characteristically accompanies exploratory behaviors (Vanderwolf, 1969) and has been suggested to serve as a temporal reference for coding the relevant environmental information represented by place cells (O'Keefe and Recce, 1993). This can explain why both exogenous and endogenous cannabinoids impair spatial memory and learning (Heyser et al., 1993; Lichtman and Martin, 1996; Mallet and Beninger, 1998). An interesting aspect of the selectivity of $\mathrm{CB} 1$ expression on the boutons of CCK-containing but not on the other type of basket cells is the possibility of selective cannabinoid actions on CCK release; this should be investigated in future studies. CCK-B receptor antagonists are known to have an anxiolytic effect (Singh et al., 1991), similar to that produced by cannabinoids (Navarro et al., 1997). The anxiolysis seen with cannabinoids may be a consequence of a CB1 receptor-mediated reduction of CCK release. This effect may override the expected reduction in inhibitory transmission caused by the CB1-mediated decrease in GABA release, a decrease predicted to be anxiogenic. At the same time, GABAergic perisomatic inhibition exerted by parvalbumin-expressing basket cells would still be fully operational and even potentiated by benzodiazepines, providing parallel routes for anxiolysis.

In summary, we have demonstrated that in the hippocampal formation the CB1 cannabinoid receptor is primarily localized on axon terminals of CCK-containing basket cells, and a major action is the inhibition of GABA release from this specific interneuron type. These results may explain the observed actions of cannabinoids on hippocampal function.

\section{REFERENCES}

Abood ME, Martin BR (1992) Neurobiology of marijuana abuse. Trends Pharmacol Sci 13:201-206.

Acsády L, Arabadzisz D, Freund TF (1996a) Correlated morphological and neurochemical features identify different subsets of vasoactive intestinal polypeptide-immunoreactive interneurons in rat hippocampus. Neuroscience 73:299-315.

Acsády L, Görcs TJ, Freund TF (1996b) Different populations of vasoactive intestinal polypeptide-immunoreactive interneurons are specialized to control pyramidal cells or interneurons in the hippocampus. Neuroscience 73:317-334.

Acsády L, Katona I, Gulyás AI, Shigemoto R, Freund TF (1997) Immunostaining for substance $P$ receptor labels GABAergic cells with distinct termination patterns in the hippocampus. J Comp Neurol 378:320-336.

Baimbridge KG, Miller JJ (1982) Immunohistochemical localization of calcium-binding protein in the cerebellum, hippocampal formation and olfactory bulb of the rat. Brain Res 245:223-229.

Baude A, Nusser Z, Roberts JD, Mulvihill E, McIlhinney RA, Somogyi P (1993) The metabotropic glutamate receptor (mGluR1 alpha) is concentrated at perisynaptic membrane of neuronal subpopulations as detected by immunogold reaction. Neuron 11:771-787.

Bernáth S, Zigmond MJ (1988) Characterization of $\left[{ }^{3} \mathrm{H}\right] \mathrm{GABA}$ release from striatal slices: evidence for a calcium-independent process via the GABA uptake system. Neuroscience 27:563-570.

Buhl EH, Halasy K, Somogyi P (1994) Diverse sources of hippocampal unitary inhibitory postsynaptic potentials and the number of synaptic release sites. Nature 368:823-828.

Caulfield MP, Brown DA (1992) Cannabinoid receptor agonists inhibit Ca current in NG108-15 neuroblastoma cells via a pertussis toxinsensitive mechanism. Br J Pharmacol 106:231-232.

Chan PK, Chan SC, Yung WH (1998) Presynaptic inhibition of GABAergic inputs to rat substantia nigra pars reticulata neurones by a cannabinoid agonist. NeuroReport 9:671-675.

Childers SR, Deadwyler SA (1996) Role of cyclic AMP in the actions of cannabinoid receptors. Biochem Pharmacol 52:819-827.

Cobb SR, Buhl EH, Halasy K, Paulsen O, Somogyi P (1995) Synchronization of neuronal activity in hippocampus by individual GABAergic interneurons. Nature 378:75-78.

Collin C, Devane WA, Dahl D, Lee CJ, Axelrod J, Alkon DL (1995) Long-term synaptic transformation of hippocampal CA1gammaaminobutyric acid synapses and the effect of anandamide. Proc Natl Acad Sci USA 92:10167-10171.

Compton DR, Gold LH, Ward SJ, Balster RL, Martin BR (1992) Aminoalkylindole analogs: cannabimimetic activity of a class of compounds structurally distinct from delta 9-tetrahydrocannabinol. J Pharmacol Exp Ther 263:1118-1126.

Constoe PF, Jones BC, Chin L (1975) Delta-9-tetrahydrocannabinol, EEG and behavior: the importance of adaptation to the testing milieu. Pharmacol Biochem Behav 3:173-177.

Coull MA, Johnston AT, Pertwee RG, Davies SN (1997) Action of delta-9-tetrahydrocannabinol on GABA(A) receptor-mediated responses in a grease-gap recording preparation of the rat hippocampal slice. Neuropharmacology 36:1387-1392.

D’Ambra TE, Estep KG, Bell MR, Eissenstat MA, Josef KA, Ward SJ, Haycock DA, Baizman ER, Casiano FM, Beglin NC, Chippari SM, Grego JD, Kullnig RK, Daley GT (1992) Conformationally restrained analogues of pravadoline: nanomolar potent, enantioselective, (aminoalkyl)indole agonists of the cannabinoid receptor. J Med Chem 35:124-135.

Deadwyler SA, Hampson RE, Mu J, Whyte A, Childers S (1995) Cannabinoids modulate voltage sensitive potassium A-current in hippocampal neurons via a cAMP-dependent process. J Pharmacol Exp Ther 273:734-743.

Devane WA, Dysarz FA, Johnson MR, Melvin LS, Howlett AC (1988) Determination and characterization of a cannabinoid receptor in rat brain. Mol Pharmacol 34:605-613.

Devane WA, Hanus L, Breuer A, Pertwee RG, Stevenson LA, Griffin G, Gibson D, Mandelbaum A, Etinger A, Mechoulam R (1992) Isolation and structure of a brain constituent that binds to the cannabinoid receptor. Science 258:1946-1949.

Freund TF, Buzsáki G (1996) Interneurons of the hippocampus. Hippocampus 6:347-470.

Gao B, Fritschy JM (1994) Selective allocation of GABAA receptors 
containing the alpha 1 subunit to neurochemically distinct subpopulations of rat hippocampal interneurons. Eur J Neurosci 6:837-853.

Gessa GL, Casu MA, Carta G, Mascia MS (1998) Cannabinoids decrease acetylcholine release in the medial prefrontal cortex and hippocampus, reversal by SR141716A. Eur J Pharmacol 21:119-124.

Gifford AN, Ashby Jr CR (1996) Electrically evoked acetylcholine release from hippocampal slices is inhibited by the cannabinoid receptor agonist, WIN 55212-2, and is potentiated by the cannabinoid antagonist, SR 141716A. J Pharmacol Exp Ther 277:1431-1436.

Gifford AN, Samiian L, Gatley SJ, Ashby Jr CR (1997) Examination of the effect of the cannabinoid receptor agonist, CP 55,940, on electrically evoked transmitter release from rat brain slices. Eur J Pharmacol 324:187-192.

Gulyás AI, Görcs TJ, Freund TF (1990) Innervation of different peptidecontaining neurons in the hippocampus by GABAergic septal afferents. Neuroscience 37:31-44.

Hájos N, Papp EC, Acsády L, Levey AI, Freund TF (1998) Distinct interneuron types express $\mathrm{m} 2$ muscarinic receptor immunoreactivity on their dendrites or axon terminals in the hippocampus. Neuroscience 82:355-376.

Hársing Jr LG, Zigmond MJ (1998) Postsynaptic integration of cholinergic and dopaminergic signals on medium-sized GABAergic projection neurons in the neostriatum. Brain Res Bull 45:607-613.

Herkenham M, Lynn AB, Little MD, Johnson MR, Melvin LS, de Costa BR, Rice KC (1990) Cannabinoid receptor localization in brain. Proc Natl Acad Sci USA 87:1932-1936.

Herkenham M, Lynn AB, Johnson MR, Melvin LS, de Costa BR, Rice KC (1991) Characterization and localization of cannabinoid receptors in rat brain: a quantitative in vitro autoradiographic study. J Neurosci 11:563-583.

Heyser CJ, Hampson RE, Deadwyler SA (1993) Effects of delta-9tetrahydrocannabinol on delayed match to sample performance in rats: alterations in short-term memory associated with changes in task specific firing of hippocampal cells. J Pharmacol Exp Ther 264:294-307.

Iversen LL, Kelly JS (1975) Uptake and metabolism of gammaaminobutyric acid by neurones and glial cells. Biochem Pharmacol 24:933-938.

Jansen EM, Haycock DA, Ward SJ, Seybold VS (1992) Distribution of cannabinoid receptors in rat brain determined with aminoalkylindoles. Brain Res 575:93-102.

Katsumaru H, Kosaka T, Heizmann CW, Hama K (1988) Immunocytochemical study of GABAergic neurons containing the calcium-binding protein parvalbumin in the rat hippocampus. Exp Brain Res 72:347-362.

Kelly JS, Dick F (1976) Differential labeling of glial cells and GABA inhibitory interneurons and nerve terminals following the microinjection of $(\beta-3)$ alanine. In: Cold Spring Harbor symposia on quantitative biology, XL, the synpase, pp 93-106. Cold Spring Harbor, NY: Cold Spring Harbor Laboratory.

Kosaka T, Kosaka K, Tateishi K, Hamaoka Y, Yanaihara N, Wu JY, Hama K (1985) GABAergic neurons containing CCK-8-like and/or VIP-like immunoreactivities in the rat hippocampus and dentate gyrus. J Comp Neurol 239:420-430.

Kujtan PW, Carlen PL, Kapur BM (1983) delta 9-Tetrahydrocannabinol and cannabidiol: dose-dependent effects on evoked potentials in the hippocampal slice. Can J Physiol Pharmacol 61:420-426.

Lévenes C, Daniel H, Soubrie P, Crepel F (1998) Cannabinoids decrease excitatory synaptic transmission and impair long-term depression in rat cerebellar Purkinje cells. J Physiol (Lond) 510:867-879.

Lichtman AH, Martin BR (1996) Delta 9-tetrahydrocannabinol impairs spatial memory through a cannabinoid receptor mechanism. Psychopharmacology (Berl) 126:125-131.

Lichtman AH, Dimen KR, Martin BR (1995) Systemic or intrahippocampal cannabinoid administration impairs spatial memory in rats. Psychopharmacology (Berl) 119:282-290.

Limberger N, Spath L, Starke K (1986) Release of previously incorporated gamma- $\left[{ }^{3} \mathrm{H}\right]$ aminobutyric acid in rabbit caudate nucleus slices. J Neurochem 46:1102-1108.

Lipparini F, Scotti de Carolis A, Longo VG (1969) A neuropharmacological investigation of some transtetra-hydrocannabinol derivatives. Physiol Behav 4:527-532.

Maccaferri G, McBain CJ (1995) Passive propagation of LTD to stratum oriens-alveus inhibitory neurons modulates the temporoammonic input to the hippocampal CA1 region. Neuron 15:137-145.
Mackie K, Hille B (1992) Cannabinoids inhibit N-type calcium channels in neuroblastoma-glioma cells. Proc Natl Acad Sci USA 89:3825-3829.

Mackie K, Lai Y, Westenbroek R, Mitchell R (1995) Cannabinoids activate an inwardly rectifying potassium conductance and inhibit Q-type calcium currents in AtT20 cells transfected with rat brain cannabinoid receptor. J Neurosi 15:6552-6561.

Mailleux P, Vanderhaeghen JJ (1992) Distribution of neuronal cannabinoid receptor in the adult rat brain: a comparative receptor binding radioautography and in situ hybridization histochemistry. Neuroscience 48:655-668.

Mallet PE, Beninger RJ (1998) Delta9-tetrahydrocannabinol, but not the endogenous cannabinoid receptor ligand anandamide, produces conditioned place avoidance. Life Sci 62:2431-2439.

Maneuf YP, Crossman AR, Brotchie JM (1996) Modulation of GABAergic transmission in the globus pallidus by the synthetic cannabinoid WIN 55,212-2. Synapse 22:382-385.

Matsuda LA, Bonner TI (1995) Molecular biology of the cannabinoid receptor. In: Cannabinoid receptors (Pertwee RG, ed), pp 117-143. London: Academic.

Matsuda LA, Lolait SJ, Brownstein MJ, Young AC, Bonner TI (1990) Structure of a cannabinoid receptor and functional expression of the cloned cDNA. Nature 346:561-564.

Matsuda LA, Bonner TI, Lolait SJ (1993) Localization of cannabinoid receptor mRNA in rat brain. J Comp Neurol 327:535-550.

Miles R, Tóth K, Gulyás AI, Hájos N, Freund TF (1996) Differences between somatic and dendritic inhibition in the hippocampus. Neuron $16: 815-823$.

Munro S, Thomas KL, Abu-Shaar M (1993) Molecular characterization of a peripheral receptor for cannabinoids. Nature 365:61-65.

Navarro M, Hernandez E, Munoz RM, del Arco I, Villanua MA, Carrera MR, Rodriguez de Fonseca F (1997) Acute administration of the CB1 cannabinoid receptor antagonist SR 141716A induces anxiety-like responses in the rat. NeuroReport 8:491-496.

Nunzi MG, Gorio A, Milan F, Freund TF, Somogyi P, Smith AD (1985) Cholecystokinin-immunoreactive cells form symmetrical synaptic contacts with pyramidal and nonpyramidal neurons in the hippocampus. J Comp Neurol 237:485-505.

Okada Y, Hassler R (1973) Uptake and release of $\gamma$-aminobutyric acid (GABA) in slices of substantia nigra of rat. Brain Res 49:214-217.

O'Keefe J, Recce ML (1993) Phase relationship between hippocampal place units and the EEG theta rhythm. Hippocampus 3:317-330.

Pacheco M, Childers SR, Arnold R, Casiano F, Ward SJ (1991) Aminoalkylindoles: actions on specific G protein-linked receptors. J Pharmacol Exp Ther 257:170-183.

Paton GS, Pertwee RG, Davies SN (1998) Correlation between cannabinoid mediated effects on paired pulse depression and induction of long term potentiation in the rat hippocampal slice. Neuropharmacology 37:1123-1130.

Penttonen M, Kamondi A, Acsády L, Buzsáki G (1998) Gamma frequency oscillation in the hippocampus of the rat: intracellular analysis in vivo. Eur J Neurosci 10:718-728.

Pertwee RG (1997) Pharmacology of cannabinoid CB1 and CB2 receptors. Pharmacol Ther 74:129-180.

Pettit DA, Harrison MP, Olson JM, Spencer RF, Cabral GA (1998) Immunohistochemical localization of the neural cannabinoid receptor in rat brain. J Neurosci Res 51:391-402.

Rinaldi-Carmona M, Barth F, Héaulme M, Shire D, Calandra B, Congy C, Martinez S, Maruani J, Néliat G, Caput D, Ferrara P, Soubrié P, Bréliere JC, Le Fur G (1994) SR141716A, a potent and selective antagonist of the brain cannabinoid receptor. FEBS Lett 350:240-244.

Sagratella S, Pezzola A, Scotti de Carolis A (1986) An EEG investigation on nabilone, a synthetic cannabinoid, in rabbits. Pharmacol Res Commun 18:653-662.

Schlicker E, Timm J, Zentner J, Gothert M (1997) Cannabinoid CB1 receptor-mediated inhibition of noradrenaline release in the human and guinea-pig hippocampus. Naunyn Schmiedebergs Arch Pharmacol 356:583-589.

Shen M, Thayer SA (1998) The cannabinoid agonist Win55212-2 inhibits calcium channels by receptor-mediated and direct pathways in cultured rat hippocampal neurons. Brain Res 783:77-84.

Shen M, Piser TM, Seybold VS, Thayer SA (1996) Cannabinoid receptor agonists inhibit glutamatergic synaptic transmission in rat hippocampal cultures. J Neurosci 16:4322-4334.

Singh L, Lewis AS, Field MJ, Hughes J, Woodruff GN (1991) Evidence 
for an involvement of the brain cholecystokinin B receptor in anxiety. Proc Natl Acad Sci USA 88:1130-1133.

Soltész I, Deschenes M (1993) Low- and high-frequency membrane potential oscillations during theta activity in CA1 and CA3 pyramidal neurons of the rat hippocampus under ketamine-xylazine anesthesia. J Neurophysiol 70:97-116.

Stella N, Piomelli D (1998) Receptor-dependent formation of 2-arachidonylglycerol (2-AG), an endogenous cannabinoid ligand. Soc Neurosci Abstr 24:1245.

Stella N, Schweitzer P, Piomelli D (1997) A second endogenous cannabinoid that modulates long-term potentiation. Nature 388:773-778.

Szabó B, Dorner L, Pfreundtner C, Norenberg W, Starke K (1998) Inhibition of GABAergic inhibitory postsynaptic currents by cannabinoids in rat corpus striatum. Neuroscience 85:395-403.

Tsou K, Brown S, Sañudo-Peña MC, Mackie K, Walker JM (1998) Immunohistochemical distribution of cannabinoid CB1 receptors in the rat central nervous system. Neuroscience 83:393-411.

Tsou K, Mackie K, Sañudo-Peña MC, Walker JM (1999) Cannabinoid CB1 receptors are primarily localized on cholecystokinin-containing GABAergic interneurons in the rat hippocampal formation. Neuroscience, in press.

Vanderwolf CH (1969) Hippocampal electrical activity and voluntary movement in the rat. Electroencephalogr Clin Neurophysiol 26:407-418.
Vardaris RM, Weisz DJ (1977) delta9-tetrahydrocannabinol and the hippocampus: effects on CA1 field potentials in rats. Brain Res Bull 2:181-187.

Vizi ES (1998) Different temperature dependence of carrier-mediated (cytoplasmic) and stimulus-evoked (exocytotic) release of transmitter: a simple method to separate the two types of release. Neurochem Int 33:359-366.

Vizi ES, Kiss JP (1998) Neurochemistry and pharmacology of the major hippocampal transmitter systems: synaptic and non-synaptic interactions. Hippocampus 8:566-607.

Ward SJ, Mastriani D, Casiano F, Arnold R (1990) Pravadoline: profile in isolated tissue preparations. J Pharmacol Exp Ther 255:1230-1239.

Weisz DJ, Gunnell DL, Teyler TJ, Vardaris RM (1982) Changes in hippocampal CA1 population spikes following administration of delta9-THC. Brain Res Bull 8:155-162.

Whittington MA, Traub RD, Jefferys JG (1995) Synchronized oscillations in interneuron networks driven by metabotropic glutamate receptor activation. Nature 373:612-615.

Willinsky MD, Scotti de Carolis A, Longo VG (1973) EEG and behavioral effects of natural, synthetic and biosynthetic cannabinoids. Psychopharmacologia 31:365-374.

Ylinen A, Soltész I, Bragin A, Penttonen M, Sík A, Buzsáki G (1995) Intracellular correlates of hippocampal theta rhythm in identified pyramidal cells, granule cells, and basket cells. Hippocampus 5:78-90. 